\title{
PENGARUH KEPEMIMPINAN DAN BUDAYA ORGANISASI TERHADAP KINERJA KARYAWAN PADA BANK DKI CABANG PEMBANTU PONDOK LABU - JAKARTA SELATAN
}

\author{
Denok Sunarsi, S.Pd., M. M., CHt. \\ Dosen Fakultas Ekonomi Universitas Pamulang \\ Email : denoksunarsi@gmail.com
}

\begin{abstract}
ABSTRAK
Penelitian ini bertujuan untuk mengetahui bagaimana Kepemimpinan dan Budaya Organisasi yang ada maupun yang diterapkan dan mengetahui bagaimana Kinerja Karyawan Pada Bank DKI Cabang Pembantu Pondok Labu - Jakarta Selatan.

Metode penelitian ini yang digunakan adalah penelitian analisis deskriptif atau kuantitatif, yang artinya penelitian ini hanya sebatas pengungkapan suatu permasalahan yang ada dan mencoba menemukan solusi atau pemecahan masalah yang ada. Pengambilan sampel menggunakan sampel yang representatif dimana penulis menggunakan sampel jenuh dengan populasi sebanyak 54 karyawan. Teknik pengumpulan data dalam penelitian ini dengan menggunakan kuesioner. Data yang diperoleh dari kuesioner dengan jumlah responden 54 orang. Analisis menggunakan bantuan program Microsoft Excel 2007 dan program SPSS versi 22 untuk melakukan Uji Validitas, Reliabilitas, Asumsi Klasik, Normalitas, Heteroskedastisitas, Multikolinieritas, Autokorelasi, Statistik, Analisis Regresi Linear, Koefisien Determinasi Parsial (t), Koefisien Determinasi Simultan, Hipotesis.

Hasil penelitian sebagai berikut : Hasil analisis regresi menunjukkan koefisien kepemimpinan sebesar 0.364 bertanda positif dan budaya organisasi sebesar 0.632 , serta diperoleh persamaan regresi $\mathrm{Y}=15.293+0.364 \mathrm{X}_{1}+0.632 \mathrm{X}_{2}$. Dari pengujian hipotesis menggunakan uji statistik $F_{\text {hitung }}=23.912>3,180$ atau $\left(F_{\text {hitung }}>F_{\text {tabel }}\right)$ sehingga $\mathrm{H}_{0}$ ditolak dan $\mathrm{H}_{1}$ diterima. Artinya terdapat pengaruh positif dan signifikan secara simultan antara kepemimpinan dan budaya organisasi terhadap kinerja karyawan Bank DKI Cabang Pembantu Pondok Labu - Jakarta Selatan.
\end{abstract}

Kata Kunci : Kepemimpinan, Budaya Organisasi, Kinerja 


\section{PENDAHULUAN}

\section{Latar Belakang}

Dalam suatu organisasi faktor kepemimpinan memegang peranan yang sangat penting karena pemimpin itulah yang akan menggerakkan dan mengarahkan organisasi dalam mencapai tujuan dan sekaligus merupakan tugas yang tidak mudah. Kepemimpinan adalah suatu proses kegiatan seseorang untuk menggerakkan orang lain dengan memimpin, membimbing, mempengaruhi orang lain, untuk melakukan sesuatu agar dicapai hasil yang diharapkan (Edy Sutrisno, 2009:213). Mengingat bahwa apa yang digerakkan oleh seorang pemimpin bukan benda mati, tetapi manusia yang mempunyai perasaan dan akal, serta beraneka ragam jenis dan sifatnya, maka masalah kepemimpinan tidak dapat dipandang mudah. Tidak mudah memberikan definisi kepemimpinan yang sifatnya universal dan diterima semua pihak yang terlibat dalam kehidupan organisasional, termasuk organisasi bisnis. Salah satu tantangan yang cukup berat yang harus dihadapi oleh pemimpin adalah bagaimana ia dapat menggerakkan kemampuan bawahannya agar senantiasa mau dan bersedia mengarahkan kemampuannya yang terbaik untuk kepentingan kelompok dan organisasinya.

Setiap organisasi memiliki ciri khas yang membedakannya dengan organisasi lain, ciri khas ini menjadi identitas bagi organisasi. Ciri khas inilah yang dinamakan budaya organisasi.Budaya organisasi adalah suatu kerangka kerja yang menjadi pedoman tingkah laku sehari-hari dan membuat keputusan untuk karyawan dan mengarahkan tindakan mereka untuk mencapai tujuan organisasi (Rivai dan Mulyadi, 2012:375). Budaya organisasi mengacu pada hubungan yang unik dari norma-norma, nilai-nilai, kepercayaan dan cara berperilaku yang menjadi ciri bagaimana kelompok dan individu dalam menyelesaikan sesuatu
Keberhasilan suatu organisasi sangat erat kaitannya dengan kulaitas kinerja para anggotanya, sehingga organisasai dituntut untuk selalu mengembangkan dan meningkatkan kinerja dari para anggotanya.Kinerja berarti hasil kerja yang dapat ditampilkan atau penampilan kerja seseorang pegawai.Dengan demikian, kinerja seorang karyawan dapat diukur dari hasil kerja, hasil tugas, atau hasil kegiatan dalam kurun waktu tertentu (Notoatmodjo, 2009:124).

Bank DKI Cabang Pembantu Pondok Labu - Jakarta Selatan adalah organisasi yang ada di Indonesia, Dalam organisasi ini baik pemimpin maupun para karyawan harus memiliki jiwa kepemimpinan yang bertanggung jawab dan memiliki integritas yang tinggi dalam organisasi dan menunjukkan kinerja yang baik sebagai karyawan.

Berdasarkan uraian dari permasalahan diatas maka penulis tertarik untuk melakukan penelitian yang berjudul :"Pengaruh Kepemimpinan dan Budaya Organisasi Terhadap Kinerja Karyawan Pada Bank DKI Cabang Pembantu Pondok Labu - Jakarta Selatan.”.

\section{Rumusan Masalah}

Adapun rumusan masalahnya adalah:

1. Bagaimana pengaruh kepemimpinan terhadap kinerja karyawan Bank DKI Cabang Pembantu Pondok Labu Jakarta Selatan secara parsial ?

2. Bagaimana pengaruh budaya organisasi terhadap kinerja karyawan Bank DKI Cabang Pembantu Pondok Labu Jakarta Selatan secara parsial?

3. Bagaimana pengaruh kepemimpinan dan budaya organisasi terhadap kinerja karyawan Bank DKI Cabang Pembantu Pondok Labu - Jakarta Selatan secara simultan? 


\section{Kerangka Pemikiran}

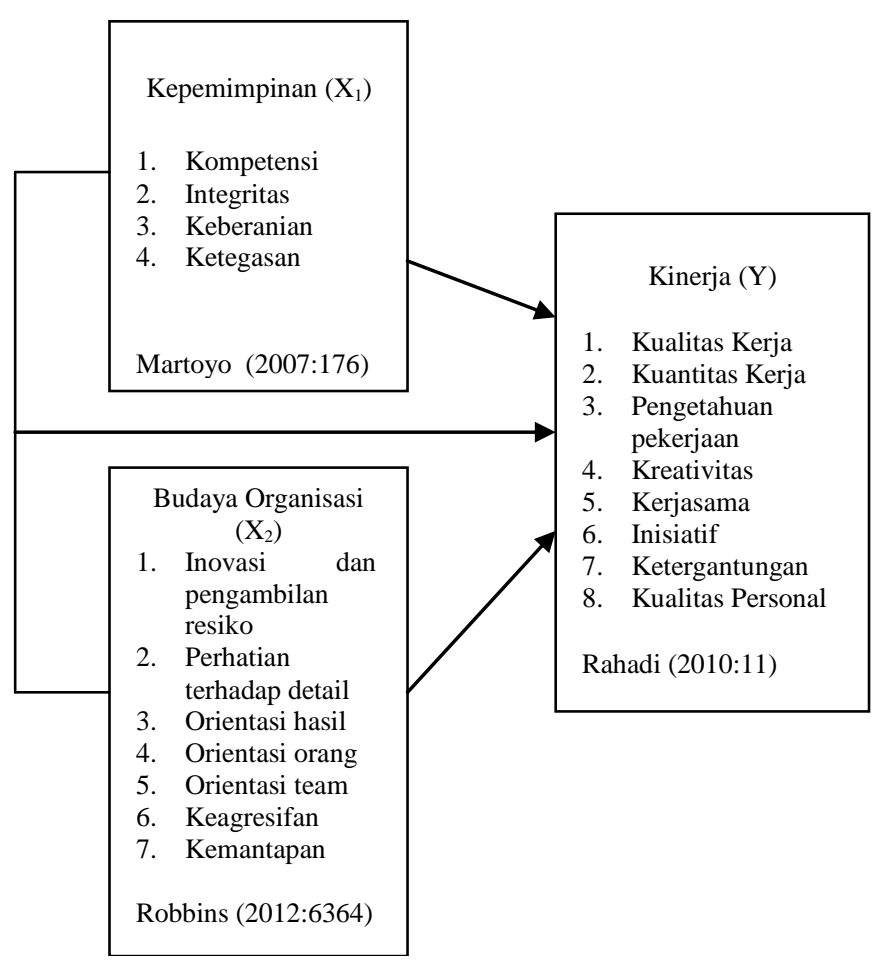

Gambar 1.1. Kerangka Pemikiran

\section{Tujuan Penelitian}

Tujuan penelitian ini adalah :

1. Untuk mengetahui pengaruh kepemimpinan terhadap kinerja karyawan Bank DKI Cabang Pembantu Pondok Labu - Jakarta Selatan secara parsial.

2. Untuk mengetahui pengaruh budaya organisasi terhadap kinerja karyawan Bank DKI Cabang Pembantu Pondok Labu - Jakarta Selatan secara parsial.

3. Untuk mengetahui kepemimpinan dan budaya organisasi terhadap kinerja karyawan Bank DKI Cabang Pembantu Pondok Labu - Jakarta Selatan secara simultan.

\section{Hipotesa Penelitian}

Berdasarkan kerangka pemikiran diatas maka dapatdisusun hipotesis sebagai berikut :

$\mathrm{H}_{1}$ : Kepemimpinan berpengaruh signifkan terhadap Kinerja karyawan Bank DKI Cabang Pembantu Pondok Labu Jakarta Selatan secara parsial.

$\mathrm{H}_{2}$ : Budaya organisasi berpengaruh signifikan terhadap Kinerja karyawan
Bank DKI Cabang Pembantu Pondok Labu - Jakarta Selatan

$\mathrm{H}_{3}$ : Kepemimpinan dan Budaya Organisasi berpengaruh sangat signifikan terhadap Kinerja karyawan Bank DKI Cabang Pembantu Pondok Labu - Jakarta Selatan secara simultan.

\section{LANDASAN TEORI \\ Kepemimpinan}

Kepemimpinan diperlukan oleh perusahaan maupun organisasi dalam upaya pencapaian tujuan organisasi. Karyawan dituntut untuk dapat mengikuti arahan dari pimpinannya karena merekalah yang dianggap mampu menjadi influence bagi karyawan untuk dapat memiliki tujuan yang sama dengan perusahaan. Jika tujuan yang dituju tidaklah sama maka akan sulit bagi suatu organisasi menjalankan proses pencapaiannya. Kepemimpinan adalah suatu proses kegiatan seseorang untuk menggerakkan orang lain dengan memimpin, membimbing, mempengaruhi orang lain, untuk melakukan sesuatu agar dicapai hasil yang diharapkan (Sutrisno, 2009:213).

\section{Budaya Organisasi}

Budaya organisasi merupakan terjemahan dari organization culture yang di definisikan dalam berbagai pengertian. Pengertian beberapa definisi budaya organisasi banyak dikemukakan oleh para ahli. Menurut Robbins (2012:63) berpendapat "Budaya organisasi adalah sehimpunan nilai, prinsip-prinsip, tradisi, dan cara-cara bekerja yang dianut bersama oleh para anggota organisasi dan mempengaruhi cara mereka bertindak".

\section{Kinerja}

Kinerja dalam bahasa inggris disebut performance, yang juga memiliki arti prestasi. Maka jika dilihat secara harfiah arti dari kinerja adalah hasil/prestasi kerja/usaha seseorang. Dalam organisasi, 
kinerja dapat diartikan sebagai pencapaian tujuan yang telah ditetapkan dalam organisasi.Organisai atau perusahaan, kinerjanya lebih tergantung pada kinerja individu tenaga kerja. Ada banyak cara untuk memikirkan tentang jenis kinerja yang dibutuhkan para tenaga kerja untuk suatu organisasi agar dapat berhasil diantaranya dengan mempertimbangkan tiga elemen yaitu produktifitas, kualitas dan pelayanan.

\section{METODOLOGI PENELITIAN}

\section{A. Metode Penelitian}

Penelitian yang dilakukan penulis pada karyawan Bank DKI Cabang Pembantu Pondok Labu - Jakarta Selatan , dilakukan dengan menggunakan metode deskriptif dengan teknik survey, yang dalam hal ini pengertian deskriptif menurut Surakhmad (2005 : 139) bahwa :

'Penyelidikan deskriptif tertuju pada pemecahan masalah yang ada pada masa sekarang. Karena banyak sekali ragam penyelidikan demikian, metode penyelidikan deskriptif lebih merupakan istilah umum yang mencakup berbagai teknik deskriptif, diantaranya ialah penyelidikan yang menuturkan, menganalisa, dan mengklasifikasikan penyelidikan dengan teknik survey, interview, angket, observasi, atau teknik test'.

Berdasarkan pengertian tersebut, penelitian yang dilakukan penulis dengan cara melihat langsung kegiatan yang dilakukan pada obyek penelitian, mencatat, menganalisis, menyimpulkan, serta menggunakannya sebagai bahan penyusunan skripsi ini.

Pendekatan analisis yang dipakai dalam penelitian ini adalah menggunakan pendekatan kuantitatif, jenis statistik yang dipakai dalam penelitian adalah statistik non parametrik. Menurut Sugiyono (2007:224):

"Statistik non parametrik digunakan untuk menguji hipotesis bila datanya berbentuk nominal atau ordinal, dan tidak berlandaskan asumsi bahwa distribusi data harus normal“".

Peneliti menggunakan statistik nonparametrik karena data yang diolah berbentuk ordinal.

\section{B. Operasionalisasi Variabel}

Istilah "Variabel" merupakan istilah yang tidak pernah ketinggalan dalam setiap jenis penelitian, F.N. Kerlinger dalam Arikunto (2006:116) menyebut variabel sebagai sebuah konsep.

Dalam penelitian ini, variabelvariabel yang akan diteliti adalah :

1. Variabel $X$ atau yang disebut variabel bebas (independen varible), varibel bebas merupakan variabel yang mempengaruhi variabel lain. Dalam penelitian ini yang merupakan variabel bebas adalah kepemimpinan dan Budaya Organisasi

2. Variabel Y atau yang disebut dengan variabel terikat (dependen variabel), variabel terikat merupakan variabel yang dipengaruhi oleh variabel lain. Dalam penelitian ini yang merupakan variabel terikat adalah kinerja.

\section{Desain Penelitian}

Jenis penelitian yang digunakan adalah deskriptif kuantitatif dengan tujuan untuk menganalisis pengaruh kepemimpinan $\left(\mathrm{X}_{1}\right)$ dan Budaya Organisasi $\left(\mathrm{X}_{2}\right)$ terhadap Kinerja $(\mathrm{Y})$. Menurut Sugiyono (2014:13) "Penelitian kuantitatif adalah metode penelitian yang berlandaskan pada filsafat positifisme, digunakan untuk meneliti pada populasi atau sampel tertentu, pengumpulan data menggunakan instrumen penelitian, analisis data bersifat kuantitatif, dengan tujuan untuk menguji hipotesis yang telah ditetapkan"

\section{Sumber dan Jenis Penelitian}

Pengertian metode penelitian menurut Sugiyono (2014:308) adalah sebagai berikut "Metode penelitian adalah cara ilmiah untuk mendapatkan data yang valid dengan tujuan dapat ditemukan, 
dapat dibuktikan, dikembangkan suatu pengetahuan tertentu sehingga pada gilirannya dapat digunakan untuk memahami, memecahkan dan mengantisipasi masalah".

1. Sumber Data

Sumber data yaitu keterangan yang benar dan nyata, yang dapat dijadikan kajian analisis atau kesimpulan dalam sebuah penelitian.

\section{a. Data Primer}

Menurut Sugiyono (2014:308) menjelaskan sumber primer adalah sebagai berikut "Sumber primer adalah sumber data yang langsung memberikan data kepada pengumpul data". Pengumpulan data primer dalam penelitian ini melalui cara menyebarkan kuesioner dan melakukan wawancara secara langsung dengan pihak-pihak yang berhubungan dengan penelitian yang dilakukan". Dalam penelitian ini data yang dipakai adalah karyawan Bank DKI Cabang Pembantu Pondok Labu - Jakarta Selatan

b. Data Sekunder

Menurut Sugiyono (2014:308) mendefinisikan data sekunder adalah sebagai berikut "Sumber sekunder adalah sumber data yang tidak langsung yang memberikan data kepada pengumpul data, misalnya orang lain atau dokumen". Dalam penelitian ini data yang dipakai adalah membaca buku, literature, seta dokumen perusahaan.

2. Jenis Data

\section{a. Data Kuantitatif}

Pengertian data kuantitatif menurut Sugiyono (2014:13) adalah "Data yang berbentuk angka atau data kuantitatif yang diangkakan".Berdasarkan pernyataan diatas bahwa metode deskriptif adalah metode yang berisi mengungkapkan pemecahan masalah yang ada sekarang berdasarkan data yang aktual, yakni dengan menyajikan data, menganalisis, dan menginterpretasikannya.Dalam hal ini data yang dimaksud adalah data berupa jumlah karyawan Bank DKI Cabang Pembantu Pondok Labu Jakarta Selatan

b. Data Kualitatif

Metode penelitian kualitatif dapat diartikan sebagai metode penelitian yang digunakan untuk meneliti pada populasi atau sampel tertentu. Menurut Sugiyono (2014:13) mengungkapkan bahwa "Masalah dalam penelitian kualitatif bersifat sementara, tentatif, dan akan berkembang atau berganti setelah peneliti berada dilapangan".

3. Obyek Penelitian

Pengertian dari obyek penelitian menurut Sugiyono (2014:13), adalah sebagai berikut "Obyek penelitian adalah sasaran ilmiah untuk mendapatkan data dengan tujuan dan kegunaan tertentu tentang sesuatu hal obyektif, valid, dan reliable tentang suatu hal (variabel tertentu)". Obyek yang akan diteliti dalam penelitian adalah karyawan Bank DKI Cabang Pembantu Pondok Labu - Jakarta Selatan

\section{E. Teknik Pengumpulan Data}

Penulis melakukan penelitian langsung ke kantor yang akan diteliti dengan menggunakanteknik sebagai berikut :

1. Observasi

Menurut Sugiyono (2014:141) mengemukakan bahwa "Observasi merupakan suatu proses yang kompleks, satu proses yang tersusun dari berbagai proses biologis dan psikologis sehingga para ilmuwan hanya dapat bekerja berdasarkan data yaitu fakta mengenai dunia kenyataan yang diperoleh melalui observasi”. 
2. Kuesioner

Menurut Sugiyono (2014:142) berpendapat bahwa Kuesioner merupakan teknik pengumpulan data yang efisien apabila peneliti tahu dengan siapa variabel akan diukur dan tahu apa yang bisa diharapkan dari responden".Kuesioner dapat berupa pertanyaan-pertanyaan tertutup maupun terbuka.

3. Wawancara

Wawancara menurut Sugiyono (2014:137) berpendapat bahwa "Wawancara merupakan metode yang digunakan untuk memperoleh informasi secara langsung, mendalam, tidak terstruktur dan individual".Dalam penelitian ini untuk mendapatkan data primer penulis melakukan wawancara secara langsung dengan pihak terkait untuk mendapatkan informasi tentang sejarah perusahaan, visi dan misi, struktur organisasi, kebijakan dan tanggung jawab masing-masing bagian.

4. Dokumentasi

Metode dokumentasi menurut Sugiyono (2014:138) yaitu "Dokumen merupakan catatan peristiwa yang sudah berlalu".Dokumen bisa berbentuk tulisan, gambar, atau karya-karya monumental dari seseorang.

5. Studi Kepustakaan

Menurut Sugiyono (2014:140), berpendapat bahwa "Studi kepustakaan berkaitan dengan kajian teoritis dan referensi lain yang berkaitan dengan nilai, budaya, dan norma yang berkembang pada situasi sosial yang diteliti, selain itu studi kepustakaan sangat penting dalam melakukan penelitian, hal ini dikarenakan penelitian tidak akanlepas dari literatur-litertur ilmiah".

\section{F. Metode Analisis Data}

\begin{tabular}{|c|c|}
\hline $\begin{array}{c}\text { Menurut } \\
\text { berpendapat }\end{array}$ & $\begin{array}{l}\text { Sugiyono } \\
\text { "Dalam }\end{array}$ \\
\hline $\begin{array}{l}\text { kuantitatif } \\
\text { nenoumnulan }\end{array}$ & $\begin{array}{l}\text { merupakan } \\
\text { data dari }\end{array}$ \\
\hline
\end{tabular}
sumber yang diperoleh". Kegiatan dalam analisis data ini menglompokkan data berdasarkan variabel dan jenisnya mentabulasi, menyajikan, dan berdasarkan variabel yang diteliti, melakukan perhitungan untuk menjawab rumusan masalah dan melakukan perhitungan untuk menguji hipotesis yang telah diajukan.

Menurut Sugiyono (2014:206) berpendapat "Metode deskriptif adalah statistik yang digunakan untuk menganalisa data dengan cara mendeskripsikan atau menggambarkan data yang telah terkumpul sebagaimana adanya tanpa membuat kesimpulan yang berlaku umum atau generalisasi". Metode deskriptif data yang digunakan dengan mengadakan pengumpulan data dan analisa sehingga diperoleh deskripsi, gambar yang jelas mengenai fakta, sifat serat pengaruh fenomena yang diteliti.Metode Kuantitatif digunakan untuk mengetahui berapa besar pengaruh variabel bebas terhadap variabel terikat.

Dalam penelitian ini instrumen yang digunakan untuk mengukur variabel penelitian tentunya harus memiliki skala pengukuran (Sugiyono, 2014:92).Skala pengukuran merupakan kesepakatan yang digunakan sebagai acuan untuk menentukan panjang pendeknya interval yang ada dalam alat ukur sehingga bila digunakan dalam penelitian ini adalah Likert.Menurut Sugiyono (2014:93) bahwa dalam penelitian sosial yang instrumennya menggunakan skala Likert, data yang diperoleh adalah interval".Dengan skala Likert, maka variabel yang diukur dijabarkan menjadi indikator 
variabel. Nilai variabel dengan instrumen tertentu dapat dinyatakan dalam bentuk angka, sehingga akan lebih akurat, efisien dan komunikatif. Jawaban setiap item instrumen yang menggunakan skala likert mempunyai gradiasi diantaranya dapat berupa kata-kata sebagai berikut :

\section{Skala Likert}

\begin{tabular}{|l|l|l|}
\hline Jawaban & Kode & $\begin{array}{l}\text { Bobot } \\
\text { Skor }\end{array}$ \\
\hline Sangat Setuju & SS & 5 \\
\hline Setuju & S & 4 \\
\hline Kurang Setuju & KS & 3 \\
\hline Tidak Setuju & TS & 2 \\
\hline Sangat Tidak Setuju & STS & 1 \\
\hline Sumber: Sugiyono (2014:93)
\end{tabular}

Untuk menentukan rentang skala dari setiap variabel, dapat ditetapkan interval untuk memberikan interpretasi, yaitu :

Kriteria Rentang Skala Variabel (X) Dan Variabel (Y)

\begin{tabular}{|l|c|l|}
\hline \multirow{2}{*}{$\begin{array}{c}\text { Skala } \\
\text { Skor }\end{array}$} & $\begin{array}{c}\text { Rentang } \\
\text { Skala }\end{array}$ & $\begin{array}{l}\text { Jawaban } \\
\text { Variabel (X) } \\
\text { dan } \\
\text { Variabel Y }\end{array}$ \\
\hline 5 & $4,20-5,00$ & $\begin{array}{l}\text { Sangat } \\
\text { Setuju }\end{array}$ \\
\hline 4 & $3,40-4,19$ & Setuju \\
\hline 3 & $2,60-3,39$ & $\begin{array}{l}\text { Kurang } \\
\text { Setuju }\end{array}$ \\
\hline 2 & $1,80-2,59$ & Tidak Setuju \\
\hline 1 & $1,00-1,79$ & $\begin{array}{l}\text { Sangat Tidak } \\
\text { Setuju }\end{array}$ \\
\hline
\end{tabular}

\section{G. Pengujian Instrumen}

\section{Pengujian Instrumen Penelitian dan Data Penelitian}

a. Validitas

Instrumen penelitian diuji coba dengan tujuan untuk mengetahui apakah instrumen telah memenuhi persyaratan dilihat dari segi kesahihan/validitas maupun dari keterandalan/reliabilitasnya.

Menurut Sugiyono (2014:361) bahwa "Valid berarti terdapat kesamaan antara data yang terkumpul dengan data yang sesungguhnya".

Keampuhan instrumen di dalam penelitian mempunyai kedudukan yang paling tinggi, karena data merupakan penggambaran variabel yang diteliti dan berfungsi sebagai alat pembuktian hipotesis. Oleh karena itu benar tidaknya data tergantung dari baik tidaknya instrumen pengumpul data. Untuk menguji validitas setiap instrumen, rumus yang digunakan adalah koefisien korelasi product moment sebagai berikut :

\section{Uji Validitas Variabel X}

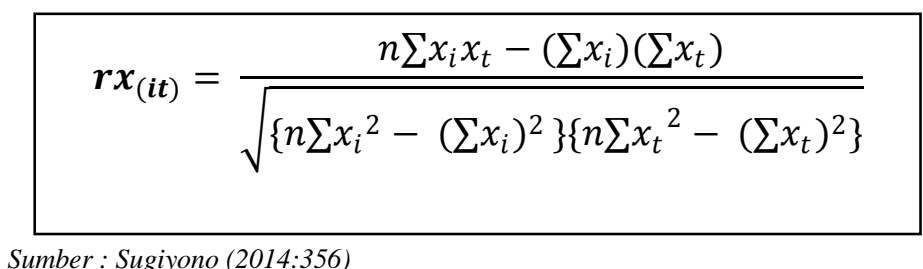

Keterangan :

$\mathrm{rx}_{(\mathrm{it})}$ : Nilai koefisien korelasi variabel $\mathrm{X}$

$\mathrm{n}$ : Banyaknya responden

$\mathrm{x}_{\mathrm{i}} \quad$ : Skor setiap item variabel $\mathrm{X}$

$x_{t} \quad$ : Skor total variabel $X$

$\sum x_{i}^{2}$ : Jumlah kuadrat skor item variabel $X$

$\sum \mathrm{x}_{\mathrm{t}}^{2}$ : Jumlah kuadrat skor total variabel $\mathrm{X}$

$\sum \mathrm{x}_{\mathrm{i}} \mathrm{x}_{\mathrm{t}}$ : Jumlah skor $\mathrm{y}_{\mathrm{i}}$ dengan skor $\mathrm{y}_{\mathrm{t}}$ variabel $X$

Uji Validitas Variabel $\mathbf{Y}$

$$
\boldsymbol{r} \boldsymbol{y}_{(\boldsymbol{i t})}=\frac{n \sum y_{i} y_{t}-\left(\sum y_{i}\right)\left(\sum y_{t}\right)}{\sqrt{\left\{n \sum y_{i}^{2}-\left(\sum y_{i}\right)^{2}\right\}\left\{n \sum y_{t}^{2}-\left(\sum y_{t}\right)^{2}\right\}}}
$$

Keterangan :

ry(it) : Nilai koefisien korelasi varibel Y 
n : Banyaknya responden

$\mathrm{y}_{\mathrm{i}} \quad$ : Skor setiap item variabel Y

$\mathrm{y}_{\mathrm{t}} \quad$ : Skor total variabel $\mathrm{Y}$

$\sum \mathrm{y}_{\mathrm{i}}^{2} \quad$ : Jumlah kuadrat skor item variable Y

$\sum \mathrm{y}_{\mathrm{t}}{ }^{2}$ : Jumlah kuadrat skor total variabel Y

$\sum \mathrm{y}_{\mathrm{i}} \mathrm{y}_{\mathrm{t}} \quad$ : Jumlah skor $\mathrm{y}_{\mathrm{i}}$ dengan skor $\mathrm{y}_{\mathrm{t}}$ variabel $\mathrm{Y}$

Uji validitas dan uji realibilitas juga dilakukan dengan dua cara :

1) Pengukuran secara berulang (Repeated Measure Method)

2) Sekali ukur (One Shot)

Dalam penelitian ini data yang digunakan adalah data interval yang diangkakan (score), serta uji validitas dan uji realibilitas menggunakan cara pengukuran sekali ukur (One Shot).

Dalam penelitian ini, untuk mengolah dan menganalisis uji validitas peneliti menggunakan korelasi Product Momentyaitu dengan mengkorelasikan skor item dengan skor total sehingga diperoleh nilai $r_{\text {hitungkemudian }}$ dibandingkan dengan $r_{\text {tabel. }}$ Menurut Sugiyono (2014:173-174), jika $r_{\text {hitung }}>$ $\mathrm{r}_{\text {tabel}}$, maka instrumen valid, sebaliknya jika $r_{\text {hitung }}<r_{\text {tabel }}$, maka dikatakan tidak valid.

\section{b. Reliabilitas}

Reliabilitas menunjuk pada pengertian bahwa sesuatu instrumen cukup dipercaya untuk digunakan sebagai alat pengumpul data karena instrumen tersebut udah baik. Instrumen yang baik tidak akan bersifat tendensius mengarahkan responden untuk memilih jawaban tertentu. Menurut Sugiyono (2014:168) berpendapat Instrumen yang reliabel jika digunakan beberapa kali untuk mengukur obyek yang sama, akan menghasilkan data yang sama. Sedangkan Imam Ghozali (2011:61) mengemukakan uji reliabilitas adalah alat uji untuk mengukur kuesioner yang merupakan indikator dari variabel.

Untuk mengukur realibilitas kuesioner dalam penelitian ini digunakan “Method Alpha Cronbach"dengan rumus :

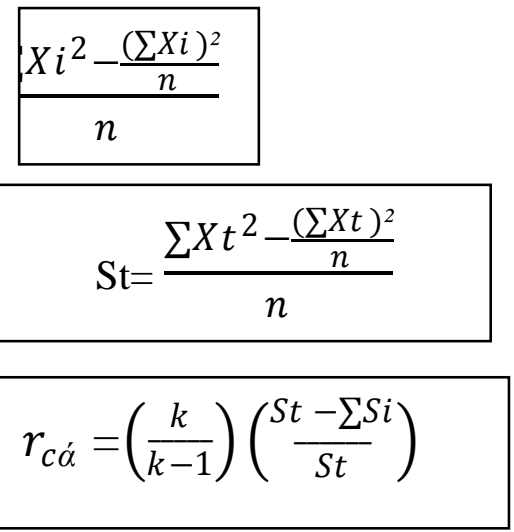

Keterangan :

$r_{\text {ca }}:$ Koefisien reliabilitas

$\mathrm{k}$ : Jumlah butir pertanyaan

$\mathrm{Si}$ : Varians skor tiap butir pertanyaan

St : Varians total pertanyaan

$\mathrm{X}_{\mathrm{i}}^{2}$ : Jumlah skor butir pertanyaan ke-n

$\mathrm{X}_{\mathrm{t}}^{2}$ : Jumlah skor total pertanyaan

n : Jumlah responden

untuk menentukan reliabel tidaknya instrumen dilakukan dengan cara membandingkan nilai $\mathrm{r}_{\text {Alpha }}$ (Cronbach Alpha) dengan $\mathrm{r}_{\text {tabel }}$ maka instrumen tersebut handal (reliable). Sebaliknya jika $\mathrm{r}_{\text {Alpha }}$ negatif atau atau $\mathrm{r}_{\text {Alpha }}$ kurang dari $\mathrm{r}_{\text {tabel }}$, maka instrumen tersebut tidak handal (not reliabel).

Apabila suatu alat ukur memberikan hasil yang stabil, maka disebut alat ukur itu handal.Hasil ukur itu diterjemahkan dengan koefisien keandalan yaitu derajat kemampuan alat ukur mengukur perbedaan-perbedaan individu yang ada.Keandalan itu perlu, sebab data yang tidak handal atau biasa tidak dapat diolah lebih lanjut karena reliabilitas dengan uji statistikCronbach Alpha $(\alpha)$.Cara menghitung tingkat reliabilitas suatu data yaitu dengan menggunakan rumus Alpha Cronbach. 
Adapun kategorisasi angka skala realibilitas yaitu :

\section{Kategorisasi Angka Skala Reliabilitas}

\begin{tabular}{|l|l|l|}
\hline No. & $\begin{array}{l}\text { Rentang } \\
\text { skala }\end{array}$ & Kategori \\
\hline 1 & $0,800-1,000$ & $\begin{array}{l}\text { Sangat Tinggi } \\
\text { (Sangat Baik) }\end{array}$ \\
\hline 2 & $0,600-0,799$ & Tinggi (Baik) \\
\hline 3 & $0,400-0,599$ & Sedang (Cukup) \\
\hline 4 & $0,200-0,399$ & Rendah (Jelek) \\
\hline 5 & $0,000-0,199$ & $\begin{array}{l}\text { Sangat Rendah } \\
\text { (Jelek) }\end{array}$ \\
\hline \multicolumn{2}{|l}{} \\
\hline
\end{tabular}

Pengukuran reliabilitas dilakukan dengan uji statistikCronbach Alpha ( $\alpha)$, suatu variabel dikatakan reliable apabila memberikan nilai Cronbach Alpha> 0,60.

\section{Pengujian Data Penelitian (Uji Asumsi Klasik)}

Uji asumsi klasik digunakan untuk mengetahui ketepatan data. Menurut Santoso (2009:342) mengemukakan "Sebuah model regresi akan digunakan untuk melakukan peramalan sebuah model yang baik adalah model dengan kesalahan peramalan yang seminimal mungkin. Karena itu sebuah model sebelum digunakan seharusnya memenuhi beberapa asumsi, yang biasa disebut asumsi klasik".

Dalam penelitian ini uji asumsi klasik yang digunakan adalah Uji Normalitas, Uji Multikolineritas, Uji Autokorelasi, dan Uji Heterokedastisitas.

\section{a. Uji Normalitas}

Uji Normalitas digunakan untuk menguji apakah dalam sebuah model regresi, variabel dependen, variabel independen, atau keduanya mempunyai distribusi normal atau tidak, Menurut Ghozali (2011:160), berpendapat'Model regresi yang baik adalah berdistribusi normal atau mendekati normal. Jadi uji normalitas bukan dilakukan pada masingmasing variabel tetapi pada nilai residualnya.Suatu data dikatakan mengikuti distribusi normal dilihat dari penyebaran data pada sumbu diagonal dari grafik". Untuk mendeteksi apakah residual berdistribusi normal atau tidak maka dengan cara melihat normal probability plotyang membandingkan distribusi kumulatif dari distribusi normal. Normalitas dapat dideteksi dengan melihat penyebaran pada (titik) pada sumbu diagonal pada grafik, dasar pengambilan keputusan adalah sebagai berikut:

1) Jika data menyebar disekitar garis diagonal dan mengikuti arah garis diagonal, maka model regresi memenuhi normalitas.

2) Jika data menyebar jauh dari garis diagonal dan tidak mengikuti arah garis diagonal, maka model regresi tidak memenuhi normalitas.

Menurut Ghozali (2011:164) :pengujian normalitas juga dapat dilakukan dengan menggunakan uji KolmogorovSmirnov Test, jikatingkat signifikansi probabilitas $>0,05$ maka data penilitian berditribusi normal".

\section{b. Uji Heteroskedastisitas}

Uji heterokedastisitas bertujuan untuk mengetahui apakah dalam model regresi terjadi kesamaan varian dari suatu residual pengamatan ke pengamatan lain. Salah satu cara untuk mendekati heteroskedastisitas adalah dengan melihat grafik scatter plotantara nilai prediksi variabel terikat (ZPRED) dengan residualnya (SRESID).

Ghozali (2011:125-126) memberikan batasan sebagai berikut :

1) Jika ada titik-titik membentuk pola tertentu yang teratur seperti gelombang, melebar, kemudian menyempit maka telah terjadi heteroskedastisitas.

2) Jika titik-titik menyebar di atas dan dibawah angka 0 pada sumbu $\mathrm{Y}$ tanpa membentuk pola tertentu maka tidak terjadi heteroskedastisitas.

Sedangkan cara untuk menganalisis asumsi Heteroskedastisitas dengan melihat grafik scatter plotdimana : 
1) Jika penyebaran data pada scatter plot teratur dan tidak membentuk pola tertentu (naik turun, mengelompok menjadi satu) maka dapat disimpulkan terjadi problem Heteroskedastisitas.

2) Jika penyebaran data pada scatter plot tidak teratur dan tidak membentuk pola tertentu (naik turun, mengelompok menjadi satu) maka dapat disimpulkan terjadi problem Heteroskedastisitas.

\section{c. Uji Multikolinearitas}

Menurut Imam Ghozali (2011:105), berpendapat bahwa "Uji multikolinearitas bertujuan untuk menguji apakah pada model regresi ditemukan adanya korelasi antar variabel bebas (independen)" .Model regresi yang baik seharusnya tidak terjadi korelasi di antara variabel indpenden.Jika variabel independen saling berkorelasi, maka variabel-variabel ini tidak ortogonal. Variabel ortogonal adalah variabel indpenden yang nilai korelasi antar sesama variabel indpenden sama dengan nol. Menurut Santoso (2009:234) "Jika model regresi terbukti ada multikolinearitas, sebaiknya salah satu dari variabel independen yang ada dikeluarkan dari model, lalu pembuatan model regresi diulang kembali".

Untuk mendeteksi ada atau tidaknya multikolinearitas di dalam model regresi adalah sebagai berikut :

1) Nilai $r^{2}$ yang dihasilkan oleh suatu estimasi model regresi empiris sangat tinggi, tetapi cara individual variabelvariabel independen banyak yang tidak signifikan mempengaruhi variabel independen.

2) Menganalisis metrik korelasi variabel-variabel indpenden, jika antara variabel independen ada korelasi yang cukup tinggi (umumnya di atas 0,90), maka hal ini merupakan indikasi adanya multikolonieritas. Tidak adanya korelasi yang tinggi antar variabel independen tidak berarti bebas dari multikolonieritas. Multikolonieritas dapat disebabkan karena adanya efek kombinasi dua atau lebih variabel independen.

3) Multikolonieritas dapat juga dilihat dari nilai tolerance dan lawannya, variance inflation factor (VIF). Kedua ukuran ini menunjukkan setiap variabel independen manakala yang dijelaskan oleh variabel independen lainnya. Tolerance mengukur variabilitas variabel independen yang terpilih yang tidak dijelaskan oleh variabel independen lainnya. Jadi nilai tolerance yang rendah sama dengan nilai VIF tinggi (karena VIF $=$ /Tolerance). Model Regresi yang baik selayaknya tidak terjadi multikolinieritas. Untuk mendeteksi hal tersebut pedomannya adalah :
a) Nilai variance inflatin factor (VIF) kurang dari 10
b) Nilai tolerance kurang dari 1
c)

\section{d. Uji Autokorelasi}

Uji Autokorelasi digunakan untuk mengetahui ada atau tidaknya penyimpangan asumsi klasik autokorelasi, yaitu adanya korelasi antar karyawan sampel yang diurutkan berdasarkan waktu. Menurut Imam Ghozali (2011:110) “Uji autokorelasi bertujuan menguji apakah dalam model rergresi linear ada korelasi antar kesalahan pengganggu pada periode $\mathrm{t}$ dengan kesalahan pengganggu pada periode $\mathrm{t}-1$.

Autokorelasi mucul karena observasi yang berurutan sepanjang waktu berkaitan satu sama lainnya.Masalah ini timbul karena residual tidak bebas darisatu observasi ke observasi lainnya.Model regresi yang baik adalah regresi yang bebas dari autokorelasi.Cara yang dapat digunakan untuk mendeteksi ada atau tidaknya autokorelasi dalam penelitian ini yaitu dengan uji Durbin-Watson (DW test).

Menurut pendapat Algifari (2010:88) "Konsekuensi dari adanya autokorelasi dalam suatu model regresi adalah varians sampel tidak dapat menjelaskan varians 
populasinya". Untuk mengetahui adanya autokorealasi dalam suatu model regresi, dilakukan pengujian Durbin-Watson (DW) dengan ketentuan sebagai berikut :

\section{Pedoman Autokorelasi Uji Durbin- Watson (Dw test)}

\begin{tabular}{|l|l|}
\hline Kriteria & Keterangan \\
\hline$<1$ & Ada autokorealsi \\
\hline $1,1-1,54$ & Tanpa kesimpulan \\
\hline $1,55-2,46$ & Tidak ada autokrelasi \\
\hline $2,46-2,9$ & Tanpa kesimpulan \\
\hline$>2,9$ & Ada autokorelasi \\
\hline
\end{tabular}

Sumber : Algifari (2010:88)

\section{Analisis Regresi Berganda}

Menurut Sugiyono (2014:277) mengemukakan bahwa "Analisis regresi digunakan untuk melakukan prediksi bagaimana perubahan nilai variabel dependen bila nilai variabel independen dinaikan/diturunkan". Sedangkan menurut pendapat Ghozali (2011:82) mengemukakan "Analisis regresi linier berganda digunakan untuk mengetahui ada tidaknya pengaruh variabel bebas terhadap variabel terikat".

Sugiyono (2014:277) memberikan model hubungan yang disusun dalam fungsi atau persamaan regresi berganda sebagai berikut :

$$
\mathrm{Y}=\mathrm{a}+\mathrm{b}_{1} \mathrm{X}_{1}+\mathrm{b}_{2} \mathrm{X}_{2}+\mathrm{e}
$$

Sumber : Sugiyono (2014:277)

Dimana :

$\mathrm{Y}=$ Kinerja karyawan

$\mathrm{a}=$ Bilangan konstanta

$b_{1}=$ Koefisien regresi variabel $X_{1}$ (Kepemimpinan)

$\mathrm{b}_{2}=$ Koefisien regresi variabel $\mathrm{X}_{2}$ (Budaya organisasi)

$\mathrm{X}_{1}=$ Kepemimpinan
$\mathrm{X}_{2}=$ Budaya organisasi

e $=$ Disturbance's error / variabel pengganggu

Besarnya konstanta tercermin dalam $(\alpha)$, dan besarnya koefisien regresi dari masing-masing variabel independen ditunjukkan dengan $b_{1}$ dan $b_{2}$.

\section{Analisis Koefisien Determinasi}

Pengertian koefisien determinasi menurut Andi Supangat (2008:350) yaitu "Koefisien determinasi adalah merupakan besaran untuk menunjukkan tingkat kekuatan hubungan antara dua variabel atau lebih dalam bentuk persen (menunjukkan seberapa besar persentase keragaman $\mathrm{Y}$ yang dapat dijelaskan oleh keragaman $\mathrm{X}_{1}$ dan $\mathrm{X}_{2}$, atau dengan kata lain seberapa besar $\mathrm{X}_{1}$ dan $\mathrm{X}_{2}$ dapat memberikan kontribusi terhadap Y".

Berdasarkan dari pengertian Sedangkan untuk mengetahui besarnya kontribusi dari $\mathrm{X}_{1}$ dan $\mathrm{X}_{2}$ terhadap nilai $\mathrm{Y}$ dapat dihitung suatu koefisien yang disebut koefisien penentuan, yang dirumuskan sebagai berikut :

$$
\mathrm{KD}=\mathrm{r}^{2} \times 100 \%
$$

Sumber : Sugiyono (2014:231)

Keterangan :

KD : Koefisien Determinasi

$\mathrm{R}$ : Koefisien Korelasi antara $\mathrm{X}_{1}, \mathrm{X}_{2}$ dan Y

$100 \%$ : Pengalian yang di prosentasikan

Besarnya kecilnya nilai koefisien determinasi ini menunjukkan besar kecilnya kontribusi atau sumbangan variabel bebas $\left(\mathrm{X}_{1}\right.$ dan $\left.\mathrm{X}_{2}\right)$ terhadap variabel terkait (Y).

\section{Pengujian Hipotesis}

Uji hipotesis diperlukan untuk menguji apakah variabel $(\mathrm{X})$ bepengaruh terhadap variabel (Y). Menurut pendapat Sugiyono (2014:213) pengertian hipotesis adalah sebagai berikut : "Hipotesis merupakan jawaban sementara terhadap 
rumusan masalah penelitian biasanya disusun dalam bentuk kalimat pertanyaan". Dengan demikian hipotesis penelitian dapat diartikan sebagai jawaban yang bersifat sementara terhadap masalah penelitian sampai terbukti melalui data yang terkumpul dan harus diuji secara empiris.

Tingkat signifikan yang dpilih dalam penelitian ini adalah 0,05(5\%) karena dinilai cukup mewakili pengaruh antara kedua variabel danmerupakan tingkat signifikan yang umum digunakan dalam penelitian ilmu-ilmu sosial. tingkat signifikansi $\quad 0,05 \quad(5 \%) \quad$ artinya kemungkinan besar dari hasil penarikan kesimpulan mempunyai probabilitas $95 \%$ atau toleransi kesalahan 5\%. Sedangkan untuk menguji diterima atau ditolaknya suatu hipotesis, maka dilakukan dengan cara uji sebagai berikut :

\section{a. Uji Parsial (Uji Statistik $t$ )}

Hubungan variabel independen secara parsial dengan variabel dependen, akan diuji dengan uji $t$ (menguji signifikansi korelasi product moment) dengan membandingkan $\mathrm{t}_{\text {tabel }}$ dengan $\mathrm{t}_{\text {hitung. }}$. Adapun rumus yang digunakan menurut Sugiyono (2014:184) dalam menguji hipotesis (Uji $t$ ) penelitian ini adalah :

$$
t_{1}=\frac{\mathrm{R}_{1} \sqrt{\mathrm{n}-2}}{\sqrt{(}\left(1-R_{1}^{2}\right)} \mathrm{dan}_{t_{1}}=\frac{\mathrm{R}_{2} \sqrt{\mathrm{n}-2}}{\sqrt{\left(1-R_{2}{ }^{2}\right)}}
$$

Sumber : Sugiyono (2014:184)

$$
\begin{aligned}
& \text { Keterangan : } \\
& \mathrm{t}=\text { Probabilitas } \\
& \mathrm{r}=\text { Koefisien korelasi } \\
& \mathrm{n}=\text { Jumlah sampel }
\end{aligned}
$$

Uji ini dugunakan untuk mengatahui apakah masing-masing variabel bebasnya secara sendiri-sendiri berpengaruh secarasignifikan terhadap variabel terikatnya. Dengan rumus hipotesis sebagai berikut :
Ho $: \mathrm{i}=0$, artinya variabel bebas secara parsial tidak mempunyai pengaruh signifikan terhadap variabel tidak bebas.

Ha $\quad: \mathrm{i} \neq 0$, artinya variabel bebas secara parsial mempunyai pengaruh signifikan terhadap variabel tidak bebas.

1) $\mathrm{t}$ hitung $>\mathrm{t}$ tabel atau probabilitas kesalahan kurang dari 10\% maka membuktikan variabel bebas secara parsial bepengaruh signifikan terhadap variabel tidak bebasnya, Ha diterima dan Ho ditolak (bepengaruh).

2) $t$ hitung $<t$ tabel atau probabilitas kesalahan lebih dari $10 \%$ maka membuktikan variabel bebas secara parsial tidak mempunyai pengaruh signifikan terhadap varibel tidak bebasnya, Ho diterima dan Ha ditolak (tidak bepengaruh).

\section{b. Uji F (Uji Serentak/Simultan)}

Uji $F$ digunakan untuk mengetahui ada dan tidaknya pengaruh bersama (simultan) variabel bebas kepemimpinan dan budaya organisasi terhadap variabel terikat atau tidak bebas kinerja karyawan.Menurut Sugiyono (2014:252) menggunakan bahwa "Uji F digunakan untuk mengetahui pengaruh secara bersama-sama variabel independen terhadap variabel dependen".Untuk menguji adanya hubungan antara variabel bebas $\left(\mathrm{X}_{1}\right.$ dan $\left.\mathrm{X}_{2}\right)$ secara simultan berdampak terhadap variabel terkait $(\mathrm{Y})$ dilakukan perhitungan dengan rumus sebagai berikut :

$$
\text { Fhitung }=\frac{\mathrm{R}^{2} / \mathrm{k}}{\left(1-R^{2}\right) /(n-k-1)}
$$

Sumber :Sugiyono (2014:252)

Dimana :

$$
\begin{array}{ll}
\mathrm{R}^{2} & =\text { Koefisien korelasi ganda } \\
\mathrm{k} & =\text { Jumlah variabel independen } \\
\mathrm{n} & =\text { Jumlah data (sampel responden) }
\end{array}
$$


Untuk menguji adanya hubungan antara variabel bebas $\left(\mathrm{X}_{1}\right.$ dan $\left.\mathrm{X}_{2}\right)$ secara simultan berdampak terhadap variabel terikat (Y) maka pengujian dilakukan dengan menggunakan uji statistik $F$. Selanjutnya untuk menguji kebenaran dan koefisien regresi secara keseluruhan atau secara simultan berdampak terhadap variabel dependen, maka membandingkan antara hasil $\mathrm{F}_{\text {hitung }}$ dan $\mathrm{F}_{\text {tabel }}$.

Adapun kriteria penolakan dan penerimaan hipotesis Ho adalah sebagai berikut :

1) Jika $F_{\text {hitung }}<F_{\text {tabel }}$, maka kepemimpinan dan budaya organisasi secara simultan tidak berpengaruh signifikan terhadap kinerja karyawan.

2) Jika $F_{\text {hitung }}>F_{\text {tabel }}$, maka kepemimpinan dan budaya organisasi secara simultan bepengaruh signifikan terhadap kinerja karyawan.

Untuk mengetahui signifikan atau tidak pengaruh secara bersama-sama variabel bebas terhadap variabel tidak bebas atau terikat maka digunakan probability sebesar $5 \%(\alpha=0,05)$.

Jika sig $>\alpha(0,05)$, maka Ho diterima H1 ditolak

Jika sig $<\alpha(0,05)$, maka Ho ditolak H1 diterima

\section{H. Operasional Variabel Penelitian}

Pengertian variabel menurut Sugiyono (2014:63) adalah sebagai berikut : "Variabel penlitian adalah suatu atribut atau sifat atau nilai dari orang objek atau kegiatan yang mempunyai variasi yang tertentu yang diterapkan oleh peneliti untuk dipelajari dan kemudian ditarik kesimpulannya". Dalam penelitian yang dilakukan penulis terdiri dari dua variabel, yaitu variabel independen antara lain :Kepemimpinan $\left(\mathrm{X}_{1}\right)$ dan Budaya organisasi $\left(\mathrm{X}_{2}\right)$ serta variabel Kinerja karyawan $(\mathrm{Y})$.

Adapun penjelasan dari masingmasing variabel itu adalahsebagai berikut :
1. Kepemimpinan menurut Martoyo (2007:176) mendefinisikan kepemimpinan adalah keseluruhan pengaruh aktifitas dalam rangka mempengaruhi orang-orang agar mau bekerja sama untuk mencapai suatu tujuan yang memang diinginkan bersama. Selanjutnya indikator kepemimimpinan meliputi :
a. Kompetensi
b. Integritas
c. Keberanian
d. Ketegasan

2. Budaya organisasi menurut Robbins (2012:63-64) yaitu "Sehimpunan nilai, prinsipprinsip, tradisi, dan cara-cara bekerja yang dianut bersama oleh para anggota organisasi dan mempengaruhi cara mereka bertindak". Adapun indikatornya adalah :
a. Inovasi dan pengambilan resiko
b. Perhatian terhadap detail
c. Orientasi hasil
d. Orientasi orang
e. Orientasi tim
f. Keagresifan
g. Kemantapan

3. Kinerja menurut Rahadi (2010:1), kinerja merupakan terjemahan dari performance yang berarti prestasi kerja, pelaksanaan kerja, pencapaian kerja, unjuk kerja atau penampilan kerja. Selanjutnya Indikatornya yaitu :
a. Kualitas kerja
b. Kuantitas kerja
c. Pengetahuan pekerjaan
d. Kreatifitas
e. Kerjasama
f. Inisiatif
g. Ketergantungan
h. Kualitas personal

Adapun operasional variabel dalam penelitian ini dibuat secara rinci seperti terlihat dibawah ini : 


\section{Definisi Operasional Variebel}

\begin{tabular}{|c|c|c|}
\hline Variabel & Indikator & Definisi \\
\hline $\begin{array}{l}\text { Kepemimpi } \\
\text { nan }\left(\mathrm{X}_{1}\right) \\
\text { Sumber: } \\
\text { Martoyo } \\
(2007: 176)\end{array}$ & $\begin{array}{l}\text { 1. Kompetensi } \\
\text { 2. Integritas } \\
\text { 3. Keberanian } \\
\text { 4. Ketegasan }\end{array}$ & $\begin{array}{l}\text { Keseluruhan } \\
\text { pengaruh aktifitas } \\
\text { dalam rangka } \\
\text { mempengaruhi } \\
\text { orang-orang agar } \\
\text { mau bekerja sama } \\
\text { untuk mencapai } \\
\text { suatu tujuan yang } \\
\text { memang } \\
\text { diinginkan } \\
\text { bersama. }\end{array}$ \\
\hline $\begin{array}{l}\text { Budaya } \\
\text { Organisasi } \\
\left(\mathrm{X}_{2}\right) \\
\text { Sumber: } \\
\text { Robbins } \\
(2012: 63- \\
64)\end{array}$ & 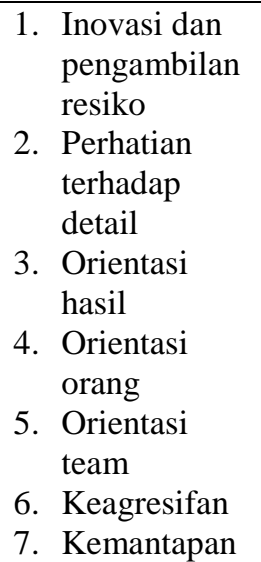 & $\begin{array}{l}\text { Sehimpunan nilai, } \\
\text { prinsip-prinsip, } \\
\text { tradisi, dan cara- } \\
\text { cara bekerja yang } \\
\text { dianut bersama } \\
\text { oleh para anggota } \\
\text { organisasi dan } \\
\text { mempengaruhi } \\
\text { cara mereka } \\
\text { bertindak. }\end{array}$ \\
\hline $\begin{array}{l}\text { Kinerja (Y) } \\
\text { Sumber: } \\
\text { Rahadi } \\
(2010: 1)\end{array}$ & $\begin{array}{l}\text { 1. Kualitas kerja } \\
\text { 2. Kuantitas } \\
\text { kerja } \\
\text { 3. Pengetahuan } \\
\text { pekerjaan } \\
\text { 4. Kreatifitas } \\
\text { 5. Kerasama } \\
\text { 6. Inisiatif } \\
\text { 7. Ketergantung } \\
\text { an } \\
\text { 8. Kualitas } \\
\text { personal }\end{array}$ & $\begin{array}{l}\text { Terjemahan dari } \\
\text { perfomance, yang } \\
\text { berarti prestasi } \\
\text { kerja, pelaksanaan } \\
\text { kerja, pencapaian } \\
\text { kerja, unjuk kerja } \\
\text { atau penampilan } \\
\text { kerja. }\end{array}$ \\
\hline
\end{tabular}

Sumber : Kuesioner dikembangkan oleh peneliti 2017

\section{HASIL PENELITIAN}

\section{Gambaran Umum Obyek Penelitian}

Bank DKI pertama kali didirikan di Jakarta dengan nama "PT Bank Pembangunan Daerah Djakarta Raya" sebagaimana termaktub dalam Akta Pendirian Perseroan Terbatas Perusahaan Bank Pembangunan Daerah Djakarta Raya (PT Bank Pembangunan Daerah Djakarta Raya) No. 30 tanggal 11 April 1961 dibuat oleh dan di hadapan Eliza Pondaag S.H., Notaris di Jakarta, yang telah memperoleh penetapan Menteri Kehakiman Republik Indonesia dengan Surat Keputusan No.
J.A.5/31/13 tanggal 11 April 1961 dan telah didaftarkan dalam buku register di Kantor Pengadilan Negeri Jakarta No. 1274 tanggal 26 Juni 1961 serta telah diumumkan dalam Tambahan No. 206 Berita Negara Republik Indonesia No. 41 tanggal 1 Juni 1962.

Obyek penelitian pada Bank DKI kantor cabang pembantu Pondok Labu Jl. Raya Pondok Labu No. 59. Cilandak, Jakarta Selatan. Telp. 021-7660251. Faks. 021-7657184

\section{A. Karakteristik Data Responden}

Sebelum disajikan data hasil penelitian, terlebih dahulu dideskripsikan karakteristik responden berdasarkan jenis kelamin, usia, pendidikan, status, dan bagian. Pengambilan data dilakukan dengan menyebar kuesioner kepada karyawan Bank DKI Cabang Pembantu Pondok Labu - Jakarta Selatan dengan sampel 54 orang dengan data respoden sebagai berikut ;

\section{Responden Berdasarkan Jenis Kelamin}

Tabel 4.1

Karakteristik Responden Berdasarkan Jenis Kelamin

\begin{tabular}{|cc|c|c|c|c|}
\hline & $\begin{array}{c}\text { Freque } \\
\text { ncy }\end{array}$ & $\begin{array}{c}\text { Percen } \\
\mathrm{t}\end{array}$ & $\begin{array}{c}\text { Valid } \\
\text { Percen } \\
\mathrm{t}\end{array}$ & $\begin{array}{c}\text { Cumulativ } \\
\text { e Percent }\end{array}$ \\
\hline $\begin{array}{c}\text { Vali } \\
\mathrm{d}\end{array}$ & Laki-laki & 39 & 72.2 & 72.2 & 72.2 \\
& & 15 & 27.8 & 27.8 & 100.0 \\
& Total & 54 & 100.0 & 100.0 & \\
\hline
\end{tabular}

Sumber : Data primer (data diolah peneliti dari kuesioner dengan SPSS Versi 22) 2017

Dari data tabel diatas, dapat dilihat bahwa responden yang berjenis kelamin laki-laki sebanyak 39 orang atau $72.2 \%$ dan wanita sebanyak 15 orang atau $27.8 \%$.

\section{Responden Berdasarkan Usia}

Tabel 4.2

Karakteristik Responden Berdasarkan Usia

\begin{tabular}{|l|l|l|l|l|}
\hline & & & Valid & Cumulative \\
& Frequency & Percent & Percent & Percent \\
\hline
\end{tabular}




\begin{tabular}{|r|r|r|r|r|}
\hline Valid $\begin{array}{l}16- \\
25 \\
\text { tahun } \\
26-\end{array}$ & 3 & 5.6 & 5.6 & 5.6 \\
35 & & & & \\
tahun & 11 & 20.4 & 20.4 & 25.9 \\
$>35$ & & & & \\
tahun & 40 & 74.1 & 74.1 & 100.0 \\
Total & 54 & 100.0 & 100.0 & \\
\hline
\end{tabular}

Sumber : Data Primer (data diolah peneliti dari kuesioner dengan SPSS Versi 22)2017

Dari data tabel diatas, responden yang berusia 16-25 tahun sebanyak 3 orang atau 5.6\%, usia 26-35 tahun sebanyak 11 orang atau 20.4\%, dan usia diatas 35 tahun sebanyak 40 orang atau $74.1 \%$.

\section{Responden Pendidikan}

Berdasarkan

Tabel 4.3

Karakteristik Responden Bedasarkan Pendidikan

\begin{tabular}{|c|c|c|c|c|c|}
\hline & & Frequency & Percent & $\begin{array}{l}\text { Valid } \\
\text { Percent }\end{array}$ & $\begin{array}{l}\text { Cumulative } \\
\text { Percent }\end{array}$ \\
\hline \multirow[t]{5}{*}{ Valid } & SLTA & 3 & 5.6 & 5.6 & 5.6 \\
\hline & Diploma & 1 & 1.9 & 1.9 & 7.4 \\
\hline & Sarjana & 35 & 64.8 & 64.8 & 72.2 \\
\hline & $\begin{array}{l}\text { Pasca } \\
\text { Sarjana }\end{array}$ & 15 & 27.8 & 27.8 & 100.0 \\
\hline & Total & 54 & 100.0 & 100.0 & \\
\hline
\end{tabular}

Sumber : Data primer (data diolah peneliti dari kuesioner dengan SPSS Versi 22) 2017

Dari data tabel diatas, responden yangberpendidikan SLTA sebanyak 3 orang atau $5.6 \%$, Diploma sebanyak 1 orang atau $1.9 \%$, Sarjana sebanyak 35 orang atau $64.8 \%$, Pasca Sarjana sebanyak 15 orang atau $27.8 \%$.

\section{Responden Berdasarkan Status Tabel 4.4}

Karakteristik Responden Berdasarkan Status

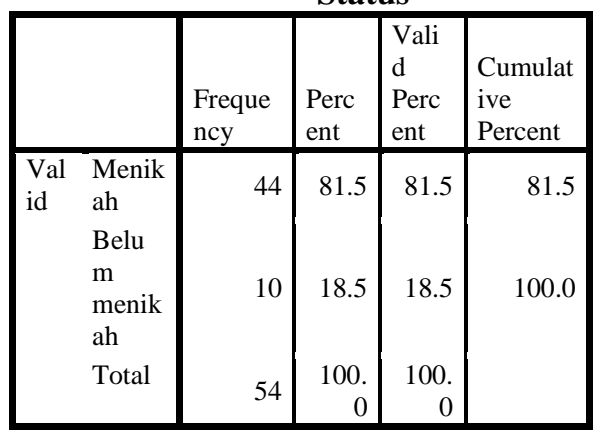

Sumber : Data primer (data diolah peneliti dari kuesioner dengan SPS Versi 22) 2017

Dari data tabel diatas, responden yang menikah sebanyak 44 orang atau
$81.5 \%$, dan sementara yang belum menikah sebanyak 10 orang atau $18.5 \%$,

\section{Responden Berdasarkan Bagian}

Tabel 4.5

Karakterisitik Responden Beradasrkan Bagian

\begin{tabular}{|c|c|c|c|c|}
\hline & $\begin{array}{l}\text { Frequen } \\
\text { cy }\end{array}$ & $\begin{array}{l}\text { Perce } \\
\text { nt }\end{array}$ & $\begin{array}{l}\text { Valid } \\
\text { Perce } \\
\text { nt }\end{array}$ & $\begin{array}{l}\text { Cumula } \\
\text { ve } \\
\text { Percent }\end{array}$ \\
\hline $\begin{array}{ll}\text { Val } & \text { karyaw } \\
\text { id } & \text { an }\end{array}$ & 9 & 16.7 & 16.7 & 16.7 \\
\hline & 31 & 57.4 & 57.4 & 74.1 \\
\hline & 14 & 25.9 & 25.9 & 100.0 \\
\hline Total & 54 & 100.0 & 100.0 & \\
\hline
\end{tabular}

Sumber : Data primer (data diolah peneliti dari kuesioner dengan SPSS Versi 22) 2017

Dari data tabel diatas, menunjukkan bahwa dari 54 responden

\section{B. Hasil Penelitian}

\section{Penilaian Responden Terhadap \\ Variabel-variabel}

Variabel yang digunakan dalam penelitian ini adalah Kepemimpinan $\left(\mathrm{X}_{1}\right)$, Budaya Organisasi $\left(\mathrm{X}_{2}\right)$, dan Kinerja karyawan (Y), penilaian dilakukan dengan menyebar kuesioner.Jumlah sampel yang diambil adalah 54 responden.

Penulis menggunakan analisis deskriptif untuk memberikan gambaran karakteristik subyek penelitian sehubungan dengan variabel yang diteliti. Sedangkan pembobotan terhadap skor masing-maisng variabel dilakukan dengan memberikan skor total dengan jumlah item melalui kuesioner.

Metode yang diambil dalam penelitian ini adalah metode pengukuran Likert.Dimana pernyataan mengandung lima alternatif jawaban. Dan bentuk pernyataan telah disusun menggunakan Likertyang diberi bobot sebagai berikut:

Tabel 4.6

Skala Likert Interpretasi

\begin{tabular}{|l|l|l|}
\hline Jawaban & Kode & $\begin{array}{l}\text { Bobot } \\
\text { Skor }\end{array}$ \\
\hline Sangat Setuju & SS & 5 \\
\hline Setuju & S & 4 \\
\hline Kurang Setuju & KS & 3 \\
\hline Tidak Setuju & TS & 2 \\
\hline Sangat Tidak Setuju & STS & 1 \\
\hline
\end{tabular}

Sumber : Sugiyono (2014:93)

Rentang skala dari setiap variabel yang diukur selanjutnya dapatditetapkan interval untuk memberikan interpretasi 
dari nilai rata-rata yang diperoleh. Adapun kriteria rentang skala dapat ditetapkan sebagai berikut :

Skala Tabel 4.7

Kriteria Rentang

\begin{tabular}{|l|l|l|}
\hline $\begin{array}{l}\text { Skala } \\
\text { Skor }\end{array}$ & $\begin{array}{l}\text { Rentang } \\
\text { Skala }\end{array}$ & Jawaban \\
\hline 5 & $4,20-5,00$ & Sangat Setuju \\
\hline 4 & $3,40-4,19$ & Setuju \\
\hline 3 & $2,60-3,39$ & Kurang Setuju \\
\hline 2 & $1,80-2,59$ & Tidak Setuju \\
\hline 1 & $1,00-1,79$ & $\begin{array}{l}\text { Sangat Tidak } \\
\text { Setuju }\end{array}$ \\
\hline
\end{tabular}

Sumber : Sugiyono (2014:93-94)

\section{a. Kepemimpinan $\left(X_{1}\right)$}

Kriteria dari obyek yang diteliti berdasarkan pada tanggapan responden pada butir pernyataan variabel kepemimpinan $\left(\mathrm{X}_{1}\right)$ yaitu sebagai berikut:

$$
\text { Tabel } 4.8
$$

Tanggapan Responden Variabel Kepemimpinan $\left(\mathbf{X}_{1}\right)$

\begin{tabular}{|c|c|c|c|c|c|c|c|}
\hline No & Pernyataan & SS & $\mathbf{S}$ & $\mathbf{S}$ & $S^{T}$ & \begin{tabular}{|l} 
ST \\
\end{tabular} & $\begin{array}{l}\text { Juml } \\
\text { ah }\end{array}$ \\
\hline \multirow[b]{2}{*}{1} & \multirow{2}{*}{\begin{tabular}{l}
\multicolumn{1}{c}{ Pimpinan } \\
erupakan seorang \\
yang memiliki \\
npetensi yang baik
\end{tabular}} & 10 & 28 & 16 & 0 & 0 & 54 \\
\hline & & $\%^{18.5}$ & $\begin{array}{l}51.9 \\
\%\end{array}$ & 29 & ${ }_{\%}^{0 .}$ & $\%^{0.0}$ & $\begin{array}{l}100.0 \\
\%\end{array}$ \\
\hline \multirow[b]{2}{*}{2} & \multirow{2}{*}{$\begin{array}{c}\text { Pimpinan } \\
\text { miliki kemampuan } \\
\text { nunikasi yang baik }\end{array}$} & 15 & 28 & 11 & 0 & 0 & 54 \\
\hline & & $\begin{array}{l}27.8 \\
\%\end{array}$ & $\begin{array}{l}51.9 \\
\%\end{array}$ & $\begin{array}{l}20 \\
\%\end{array}$ & $\%$ & $\%^{0.0}$ & $100 \%$ \\
\hline \multirow[b]{2}{*}{3} & \multirow{2}{*}{\begin{tabular}{|c|} 
Pimpinan \\
emiliki integritas \\
yang tinggi
\end{tabular}} & 17 & 23 & 14 & 0 & 0 & 54 \\
\hline & & \begin{tabular}{|l|}
31.5 \\
$\%$
\end{tabular} & $\begin{array}{l}42.6 \\
\%\end{array}$ & 25 & $\%^{0 .}$ & $\%^{0.0}$ & $100 \%$ \\
\hline \multirow[b]{2}{*}{4} & \multirow{2}{*}{$\begin{array}{c}\text { Pimpinan } \\
\text { miliki kewibawaan } \\
\text { hingga dihormati } \\
\text { dan disegani }\end{array}$} & 7 & 24 & 23 & 0 & 0 & 54 \\
\hline & & $\%^{13.0}$ & $\begin{array}{l}44.4 \\
\%\end{array}$ & 42 & $\%$ & $\%^{0.0}$ & $100 \%$ \\
\hline \multirow[b]{2}{*}{5} & \multirow{2}{*}{$\begin{array}{c}\text { Keberanian } \\
\text { pimpinan dalam } \\
\text { hgambil keputusan }\end{array}$} & 2 & 22 & 29 & 1 & 0 & 54 \\
\hline & & $3.7 \%$ & $\begin{array}{l}40.7 \\
\%\end{array}$ & $\begin{array}{l}53 \\
\%\end{array}$ & $\%$ & $\%^{0.0}$ & $100 \%$ \\
\hline \multirow[b]{2}{*}{6} & \multirow{2}{*}{$\begin{array}{c}\text { Keberanian } \\
\text { pimpinan dalam } \\
\text { nghadapi masalah } \\
\text { organisasi }\end{array}$} & 13 & 28 & 11 & 2 & 0 & 54 \\
\hline & & $\begin{array}{l}24.1 \\
\%\end{array}$ & ${ }_{\%}^{51.9}$ & 20 & $\%^{3 .}$ & $\%^{0.0}$ & $100 \%$ \\
\hline \multirow[b]{2}{*}{7} & \multirow{2}{*}{$\begin{array}{l}\text { Pimpinan berani } \\
\text { enegur karyawan } \\
\text { ang melakukan } \\
\text { kesalahan }\end{array}$} & 23 & 14 & 17 & 0 & 0 & 54 \\
\hline & & $\begin{array}{l}42.6 \\
\%\end{array}$ & $\begin{array}{l}25.9 \\
\%\end{array}$ & $\begin{array}{l}31 \\
\%\end{array}$ & $\%$ & $\%^{0.0}$ & $100 \%$ \\
\hline \multirow[b]{2}{*}{8} & \multirow{2}{*}{\begin{tabular}{|c}
\multicolumn{1}{c}{ Pimpinan } \\
herupakan orang \\
ang sangat tegas \\
am melaksanakan \\
aturan di dalam \\
organisasi \\
\end{tabular}} & 21 & 19 & 14 & 0 & 0 & 54 \\
\hline & & ${ }^{38.9}$ & ${ }^{35.2}$ & 25 & $\%$ & $\%^{0.0}$ & $100 \%$ \\
\hline \multirow[b]{2}{*}{9} & \multirow{2}{*}{\begin{tabular}{|c} 
Pimpinan \\
sikap tegas dalam \\
tiap pengambilan \\
keputusan \\
\end{tabular}} & 5 & 24 & 25 & 0 & 0 & 54 \\
\hline & & $9.3 \%$ & $\begin{array}{l}44.4 \\
\%\end{array}$ & 46 & $\%$ & $\%^{0.0}$ & $100 \%$ \\
\hline \multirow[b]{2}{*}{10} & \multirow{2}{*}{$\begin{array}{c}\text { Pimpinan } \\
\text { rrsikap adil tanpa } \\
\text { embedakan status } \\
\text { karyawan }\end{array}$} & 16 & 21 & 14 & 2 & 1 & 54 \\
\hline & & $\%^{29.6}$ & $\begin{array}{l}38.8 \\
\%\end{array}$ & 25 & $\%^{3 .}$ & $\%^{1.9}$ & $100 \%$ \\
\hline & Jumlah & 129 & 231 & 174 & 5 & 1 & 540 \\
\hline & Presentase & $\begin{array}{l}23.9 \\
\%\end{array}$ & $\begin{array}{l}42.8 \\
\%\end{array}$ & $\begin{array}{l}32 . \\
2 \%\end{array}$ & $\%$ & $\%^{0.2}$ & $100 \%$ \\
\hline
\end{tabular}

Sumber : Data Primer tahun 2017(diolah)

Berdasarkan tabel diatas, diketahui bahwa rata-rata responden menyatakan setuju, hal ini terlihat dari jawaban responden yang menyatakan setuju dan sangat setuju $(42.8 \%+23.9 \%)=66.7 \%$. Hal ini menunjukkan bahwa pendapat responden mengenai kepemimpinan sudah baik.Untuk lebih baik lagi pemimpin perlu meningkatkan kompetensi, komuikasi yang baik serta lebih berani dalam menghadapi masalah organisasi.

\section{b. Budaya Organisasi $\left(\mathbf{X}_{2}\right)$}

Kriteria dari obyek yang diteliti berdasarkan pada tanggapan responden pada butir pernyataan variabel budaya organisasi $\left(\mathrm{X}_{2}\right)$ yaitu sebagai berikut :

Tabel 4.9

Tanggapan Responden Variabel Budaya Organisasi $\left(\mathbf{X}_{2}\right)$

\begin{tabular}{|c|c|c|c|c|c|c|c|}
\hline $\begin{array}{l}\mathbf{N} \\
\mathbf{o} .\end{array}$ & Pernyataan & SS & $\mathbf{S}$ & KS & TS & $\begin{array}{c}\text { ST } \\
\text { S }\end{array}$ & $\begin{array}{c}\text { Juml } \\
\text { ah }\end{array}$ \\
\hline & \multirow[b]{2}{*}{$\begin{array}{c}\text { Pimpinan } \\
\text { mendorong } \\
\text { untuk } \\
\text { melakukan } \\
\text { inovasi/gaga } \\
\text { san baru } \\
\text { dalam } \\
\text { pekerjaan }\end{array}$} & 10 & 28 & 16 & 0 & 0 & 54 \\
\hline 1 & & $\begin{array}{c}18.5 \\
\%\end{array}$ & $\begin{array}{c}51.9 \\
\%\end{array}$ & $\begin{array}{c}29.6 \\
\%\end{array}$ & $\begin{array}{c}0.0 \\
\%\end{array}$ & $\begin{array}{c}0.0 \\
\%\end{array}$ & $100 \%$ \\
\hline \multirow[b]{2}{*}{2} & \multirow[b]{2}{*}{$\begin{array}{c}\text { Memiliki } \\
\text { kebebasan di } \\
\text { organisasi } \\
\text { dalam } \\
\text { bertindak } \\
\text { dan } \\
\text { pengambilan } \\
\text { keputusan }\end{array}$} & 7 & 33 & 14 & 0 & 0 & 54 \\
\hline & & $\begin{array}{c}13.0 \\
\%\end{array}$ & $\begin{array}{c}61.1 \\
\%\end{array}$ & $\begin{array}{c}25.9 \\
\%\end{array}$ & $\begin{array}{c}0.0 \\
\%\end{array}$ & $\begin{array}{c}0.0 \\
\%\end{array}$ & $100 \%$ \\
\hline \multirow[b]{2}{*}{3} & \multirow[b]{2}{*}{$\begin{array}{c}\text { Dalam } \\
\text { bekerja } \\
\text { cukup } \\
\text { nyaman } \\
\text { danmerasa } \\
\text { ikut } \\
\text { memiliki } \\
\text { tanggung } \\
\text { jawab yang } \\
\text { tinggi pada } \\
\text { organisasi }\end{array}$} & 15 & 20 & 19 & 0 & 0 & 54 \\
\hline & & $\begin{array}{c}27.8 \\
\%\end{array}$ & $\begin{array}{c}37.0 \\
\%\end{array}$ & $\begin{array}{c}35.2 \\
\%\end{array}$ & $\begin{array}{c}0.0 \\
\%\end{array}$ & $\begin{array}{c}0.0 \\
\%\end{array}$ & $100 \%$ \\
\hline \multirow[b]{2}{*}{4} & \multirow[b]{2}{*}{$\begin{array}{c}\text { Merasa } \\
\text { memiliki } \\
\text { kebanggaan } \\
\text { dalam } \\
\text { berpartisipas } \\
\text { i pada } \\
\text { organisasi } \\
\text { ini }\end{array}$} & 13 & 27 & 13 & 1 & 0 & 54 \\
\hline & & $\begin{array}{c}24.1 \\
\%\end{array}$ & $\begin{array}{c}50.0 \\
\%\end{array}$ & $\begin{array}{c}24.1 \\
\%\end{array}$ & $\begin{array}{c}1.9 \\
\%\end{array}$ & $\begin{array}{c}0.0 \\
\%\end{array}$ & $100 \%$ \\
\hline \multirow[b]{2}{*}{5} & \multirow{2}{*}{$\begin{array}{c}\text { Organisasi } \\
\text { selalu } \\
\text { mendorong } \\
\text { untuk } \\
\text { mencapai } \\
\text { hasil yang } \\
\text { maksimal } \\
\end{array}$} & 9 & 20 & 25 & 0 & 0 & 54 \\
\hline & & $\begin{array}{c}16.7 \\
\%\end{array}$ & $\begin{array}{c}37.0 \\
\%\end{array}$ & $\begin{array}{c}46.3 \\
\%\end{array}$ & $\begin{array}{c}0.0 \\
\%\end{array}$ & $\begin{array}{c}0.0 \\
\%\end{array}$ & $100 \%$ \\
\hline
\end{tabular}




\begin{tabular}{|c|c|c|c|c|c|c|c|}
\hline \multirow{2}{*}{6} & \multirow[b]{2}{*}{$\begin{array}{c}\text { Organisasi } \\
\text { memperhati } \\
\text { kan individu } \\
\text { yang } \\
\text { memiliki } \\
\text { kemampuan } \\
\text { bekerja yang } \\
\text { sangat baik }\end{array}$} & 11 & 31 & 12 & 0 & 0 & 54 \\
\hline & & $\begin{array}{c}20.4 \\
\%\end{array}$ & $\begin{array}{c}57.4 \\
\%\end{array}$ & $\begin{array}{c}22.2 \\
\%\end{array}$ & $\begin{array}{c}0.0 \\
\%\end{array}$ & $\begin{array}{c}0.0 \\
\%\end{array}$ & $100 \%$ \\
\hline \multirow[b]{2}{*}{7} & \multirow[b]{2}{*}{$\begin{array}{c}\text { Pimpinan } \\
\text { beserta } \\
\text { karyawan } \\
\text { mampu } \\
\text { menumbuhk } \\
\text { an } \\
\text { kehangatan } \\
\text { hubungan di } \\
\text { antara } \\
\text { sesama } \\
\text { karyawan } \\
\text { maupun } \\
\text { anggota }\end{array}$} & 14 & 21 & 19 & 0 & 0 & 54 \\
\hline & & $\begin{array}{c}25.9 \\
\%\end{array}$ & $\begin{array}{c}38.9 \\
\%\end{array}$ & $\begin{array}{c}35.2 \\
\%\end{array}$ & $\begin{array}{c}0.0 \\
\%\end{array}$ & $\begin{array}{c}0.0 \\
\%\end{array}$ & $100 \%$ \\
\hline \multirow[b]{2}{*}{8} & \multirow[b]{2}{*}{$\begin{array}{c}\text { Organisasi } \\
\text { menerapkan } \\
\text { penempatan } \\
\text { pekerjaan } \\
\text { sesuai } \\
\text { dengan skill } \\
\text { individu } \\
\text { karyawan }\end{array}$} & 12 & 22 & 20 & 0 & 0 & 54 \\
\hline & & $\begin{array}{c}22.2 \\
\%\end{array}$ & $\begin{array}{c}40.7 \\
\%\end{array}$ & $\begin{array}{c}37.0 \\
\%\end{array}$ & $\begin{array}{c}0.0 \\
\%\end{array}$ & $\begin{array}{c}0.0 \\
\%\end{array}$ & $100 \%$ \\
\hline \multirow[b]{2}{*}{9} & \multirow[b]{2}{*}{$\begin{array}{c}\text { Dalam } \\
\text { melaksanaka } \\
\text { n pekerjaan, } \\
\text { melakukan } \\
\text { koordinasi } \\
\text { dengan team } \\
\text { atau rekan } \\
\text { kerja }\end{array}$} & 9 & 25 & 17 & 3 & 0 & 54 \\
\hline & & $\begin{array}{c}16.7 \\
\%\end{array}$ & $\begin{array}{c}46.3 \\
\%\end{array}$ & $\begin{array}{c}31.5 \\
\%\end{array}$ & $\begin{array}{c}5.6 \\
\%\end{array}$ & $\begin{array}{c}0.0 \\
\%\end{array}$ & $100 \%$ \\
\hline \multirow[b]{2}{*}{10} & \multirow[b]{2}{*}{$\begin{array}{c}\text { Dalam } \\
\text { menjalankan } \\
\text { tugas dan } \\
\text { tanggung } \\
\text { jawab, } \\
\text { mendapat } \\
\text { dukungan } \\
\text { dari team }\end{array}$} & 10 & 26 & 18 & 0 & 0 & 54 \\
\hline & & $\begin{array}{c}18.5 \\
\%\end{array}$ & $\begin{array}{c}48.1 \\
\%\end{array}$ & $\begin{array}{c}33.3 \\
\%\end{array}$ & $\begin{array}{c}0.0 \\
\%\end{array}$ & $\begin{array}{c}0.0 \\
\%\end{array}$ & $100 \%$ \\
\hline \multirow[b]{2}{*}{11} & \multirow[b]{2}{*}{$\begin{array}{l}\text { karyawan } \\
\text { memiliki } \\
\text { motivasi } \\
\text { yang tinggi } \\
\text { dalam } \\
\text { memajukan } \\
\text { organisasi }\end{array}$} & 11 & 23 & 20 & 0 & 0 & 54 \\
\hline & & $\begin{array}{c}20.4 \\
\%\end{array}$ & $\begin{array}{c}42.6 \\
\%\end{array}$ & $\begin{array}{c}37.0 \\
\%\end{array}$ & $\begin{array}{c}0.0 \\
\%\end{array}$ & $\begin{array}{c}0.0 \\
\%\end{array}$ & $100 \%$ \\
\hline \multirow[b]{2}{*}{12} & \multirow[b]{2}{*}{$\begin{array}{l}\text { karyawan } \\
\text { tidak } \\
\text { canggung } \\
\text { mengusulka } \\
\text { n ide-ide } \\
\text { baru yang } \\
\text { positif }\end{array}$} & 13 & 30 & 11 & 0 & 0 & 54 \\
\hline & & $\begin{array}{c}24.1 \\
\%\end{array}$ & $\begin{array}{c}55.6 \\
\%\end{array}$ & $\begin{array}{c}20.4 \\
\%\end{array}$ & $\begin{array}{c}0.0 \\
\%\end{array}$ & $\begin{array}{c}0.0 \\
\%\end{array}$ & $100 \%$ \\
\hline \multirow[b]{2}{*}{13} & \multirow[b]{2}{*}{$\begin{array}{l}\text { karyawan } \\
\text { maupun } \\
\text { anggota } \\
\text { senantiasa } \\
\text { mentaati } \\
\text { kebijakan } \\
\text { yang ada di } \\
\text { organisasi }\end{array}$} & 9 & 32 & 13 & 0 & 0 & 54 \\
\hline & & $\begin{array}{c}16.7 \\
\%\end{array}$ & $\begin{array}{c}59.3 \\
\%\end{array}$ & $\begin{array}{c}24.1 \\
\%\end{array}$ & $\begin{array}{c}0.0 \\
\%\end{array}$ & $\begin{array}{c}0.0 \\
\%\end{array}$ & $100 \%$ \\
\hline \multirow[b]{2}{*}{14} & \multirow[b]{2}{*}{$\begin{array}{l}\text { Pimpinan } \\
\text { memiliki } \\
\text { konsepsi } \\
\text { yang jelas } \\
\text { tentang arah } \\
\text { visi dan misi } \\
\text { organisasi }\end{array}$} & 24 & 22 & 8 & 0 & 0 & 54 \\
\hline & & $\begin{array}{c}44.4 \\
\%\end{array}$ & $\begin{array}{c}40.7 \\
\%\end{array}$ & $\begin{array}{c}14.8 \\
\%\end{array}$ & $\begin{array}{c}0.0 \\
\%\end{array}$ & $\begin{array}{c}0.0 \\
\%\end{array}$ & $100 \%$ \\
\hline & Jumlah & 167 & 360 & 225 & 4 & 0 & 756 \\
\hline
\end{tabular}

\begin{tabular}{c|c|c|c|c|c|c|}
\multirow{2}{*}{ Presentase } & 22.1 & 47.6 & 29.8 & 0.5 & 0.0 & 100.0 \\
& $\%$ & $\%$ & $\%$ & $\%$ & $\%$ & $\%$ \\
\hline
\end{tabular}

Sumber : Data Primer tahun 2017(diolah)

Berdasarkan tabel diatas, tanggapan responden yang menjawab setuju, hal ini terlihat dari jawaban responden yang menyatakan setuju dan sangat setujusebesar $(47.6 \%+22.1 \%)=69.7 \%$ $\mathrm{Hal}$ ini menunjukkan bahwa pendapat responden mengenai budaya organisasi sudah baik. Maka untuk lebih baik lagi organisasi harus lebih memperhatikan individu yang memiliki kemampuan bekerja yang sangat baik dengan memberikan kebebasan dalam bertindakdan pengambilan keputusan di dalam organisasi.

\section{c. Kinerja (Y)}

Kriteriadari obyek yang diteliti berdasarkan pada tanggapan responden pada butir pernyataan variabel kinerja (Y) yaitu sebagi berikut :

Tabel 4.10

Tanggapan Responden Variabel Kinerja

\begin{tabular}{|c|c|c|c|c|c|c|}
\hline $\begin{array}{c}\text { Pernyataa } \\
\text { n }\end{array}$ & SS & $\mathbf{S}$ & KS & TS & $\begin{array}{c}\text { ST } \\
\text { S }\end{array}$ & $\begin{array}{l}\text { Jum } \\
\text { lah }\end{array}$ \\
\hline Kualitas & 12 & 31 & 11 & 0 & 0 & 54 \\
\hline $\begin{array}{c}\text { kerja } \\
\text { karyawan } \\
\text { sudah } \\
\text { sesuai } \\
\text { dengan } \\
\text { keinginan } \\
\text { organisasi }\end{array}$ & $\begin{array}{c}22.2 \\
\%\end{array}$ & $\begin{array}{c}57.4 \\
\%\end{array}$ & $\begin{array}{c}20.4 \\
\%\end{array}$ & $\begin{array}{c}0.0 \\
\%\end{array}$ & & $\begin{array}{c}100 \\
\%\end{array}$ \\
\hline Kualitas & 14 & 24 & 15 & 1 & 0 & 54 \\
\hline $\begin{array}{c}\text { kerja } \\
\text { karyawan } \\
\text { lebih baik } \\
\text { dari } \\
\text { karyawan } \\
\text { lain }\end{array}$ & $\begin{array}{c}25.9 \\
\%\end{array}$ & $\begin{array}{c}44.4 \\
\%\end{array}$ & $\begin{array}{c}27.8 \\
\%\end{array}$ & $\begin{array}{l}1.9 \\
\%\end{array}$ & $\begin{array}{l}0.0 \\
\%\end{array}$ & $\begin{array}{c}100 \\
\%\end{array}$ \\
\hline Kualntitas & 16 & 16 & 21 & 1 & 0 & 54 \\
\hline $\begin{array}{c}\text { kerja } \\
\text { karyawan } \\
\text { sudah } \\
\text { cukup } \\
\text { optimal }\end{array}$ & $\begin{array}{c}29.6 \\
\%\end{array}$ & $\begin{array}{c}29.6 \\
\%\end{array}$ & $\begin{array}{c}38.9 \\
\%\end{array}$ & $\begin{array}{l}1.9 \\
\%\end{array}$ & $\begin{array}{l}0.0 \\
\%\end{array}$ & $\begin{array}{c}100 \\
\%\end{array}$ \\
\hline Kuantitas & 19 & 26 & 8 & 1 & 0 & 54 \\
\hline $\begin{array}{c}\text { kerja } \\
\text { karyawan } \\
\text { ini lebih } \\
\text { baik dari } \\
\text { organisasi } \\
\text { lain }\end{array}$ & $\begin{array}{c}35.2 \\
\%\end{array}$ & $\begin{array}{c}48.1 \\
\%\end{array}$ & $\begin{array}{c}14.8 \\
\%\end{array}$ & $\begin{array}{l}1.9 \\
\%\end{array}$ & $\begin{array}{l}0.0 \\
\%\end{array}$ & $\begin{array}{c}100 \\
\%\end{array}$ \\
\hline Pengetahua & 11 & 20 & 22 & 1 & 0 & 54 \\
\hline $\begin{array}{l}\text { n pekerjaan } \\
\text { karyawan } \\
\text { sangat } \\
\text { membantu } \\
\text { kemajuan }\end{array}$ & $\begin{array}{c}20.4 \\
\%\end{array}$ & $\begin{array}{c}37.0 \\
\%\end{array}$ & $\begin{array}{c}40.7 \\
\%\end{array}$ & $\begin{array}{l}1.9 \\
\%\end{array}$ & $\begin{array}{l}0.0 \\
\%\end{array}$ & $\begin{array}{c}100 \\
\%\end{array}$ \\
\hline
\end{tabular}




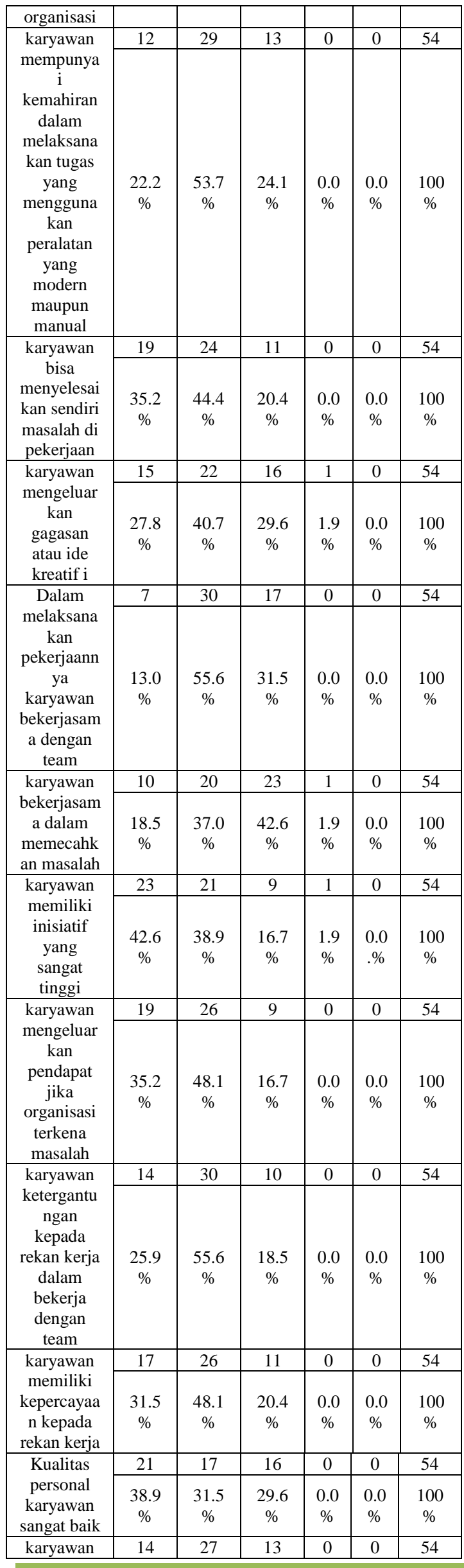

\begin{tabular}{|c|c|c|c|c|c|c|}
\hline $\begin{array}{c}\text { melakukan } \\
\text { setiap } \\
\text { pekerjaan } \\
\text { dengan } \\
\text { rapi }\end{array}$ & $\begin{array}{c}25.9 \\
\%\end{array}$ & $\begin{array}{c}50.0 \\
\%\end{array}$ & $\begin{array}{c}24.1 \\
\%\end{array}$ & $\begin{array}{c}0.0 \\
\%\end{array}$ & $\begin{array}{c}0.0 \\
\%\end{array}$ & $\begin{array}{c}100 \\
\%\end{array}$ \\
\hline Jumlah & 243 & 389 & 225 & 7 & 0 & 54 \\
\hline Presentase & $\begin{array}{c}28.1 \\
\%\end{array}$ & $\begin{array}{c}45.0 \\
\%\end{array}$ & $\begin{array}{c}26.0 \\
\%\end{array}$ & $\begin{array}{c}0.8 \\
\%\end{array}$ & $\begin{array}{c}0.0 \\
\%\end{array}$ & $\begin{array}{c}100 \\
\%\end{array}$ \\
\hline
\end{tabular}

Sumber: Data Primer tahun 2017(diolah)

Berdasarkan tabel diatas, diketahui bahwa rata-rata responden menyatakan setuju, hal ini terlihat dari jawaban responden yang menyatakan setuju dan sangat setuju sebesar $(45.0 \%+28.1 \%)=$ $73.1 \%$. Hal ini menunjukkan bahwa pendapat responden mengenai kinerja karyawan sudah baik.Untuk itu lebih baik lagi perlu meningkatkan kualitas kerja karyawan agar sesuai dengan keinginan organisasi.

\section{Hasil Pengolahan Data}

\section{A. Uji Validitas (Uji Instrumen)}

Sebelum dilakukan pengolahan data terlebih dahulu dilakukan uji validitas instrumen (butir pernyataan) yang digunakan agar dapat diketahui kelayakan dari pengguna butir pernyataan dalam penelitian yang dilakukan.Uji validitas ini digunakan untuk menguji pernyataan pada setap butir pernyataan pada kuesioner valid atau tidak, dalam arti dapat dipergunakan atau tidak.

Selanjutnya untuk mengolah uji validitas, peneliti menggunakan program SPSS versi 22 dengan kriteria sebagai berikut :

1) Jika nilai $r_{\text {hitunglebih besar dari } r_{\text {tabel }}}$ $\left(\mathrm{r}_{\text {hitung }}>\mathrm{r}_{\text {tabel }}\right)$ dan nilai $\mathrm{r}$ positif maka butir pernyataan dikatakan valid.

2) Jika nilai $r_{\text {hitung }}$ lebih kecil dari $r_{\text {tabel }}$ $\left(\mathrm{r}_{\text {hitung }}>\mathrm{r}_{\text {tabel }}\right)$ dan nilai $\mathrm{r}$ negatif maka butir pernyataan dikatakan tidak valid.

Adapun nilai $\mathrm{r}_{\text {tabel }}$ untuk 54 responden dengan taraf signifikansi $\alpha=0,05(5 \%)$ dengan tingkat kepercayaan pengujiannya adalah $95 \%$.

Berikut ini hasil perhitungan uji validitas variabel kepemimpinan $\left(\mathrm{X}_{1}\right)$ yang diolah dengan program SPSS sebagai berikut :

Pengujian validitas variabel Kepemimpinan $\left(\mathrm{X}_{1}\right)$ 
Tabel 4.11

Uji Validitas Variabel Kepemimpinan $\left(\mathbf{X}_{1}\right)$

\begin{tabular}{|c|c|c|c|c|}
\hline No & Pernyataan & $\begin{array}{c}\text { r } \\
\text { hitung }\end{array}$ & $\begin{array}{c}\text { r } \\
\text { tabel }\end{array}$ & $\begin{array}{c}\text { Ket. } \\
\text { Butir }\end{array}$ \\
\hline $\mathbf{1}$ & $\begin{array}{c}\text { Butir } \\
\text { Pernyataan 1 }\end{array}$ & 0.536 & 0,268 & Valid \\
\hline $\mathbf{2}$ & $\begin{array}{c}\text { Butir } \\
\text { Pernyataan 2 }\end{array}$ & 0.506 & 0,268 & Valid \\
\hline $\mathbf{3}$ & $\begin{array}{c}\text { Butir } \\
\text { Pernyataan 3 }\end{array}$ & 0.330 & 0.268 & Valid \\
\hline $\mathbf{4}$ & $\begin{array}{c}\text { Butir } \\
\text { Pernyataan 4 }\end{array}$ & 0.450 & 0.268 & Valid \\
\hline $\mathbf{5}$ & $\begin{array}{c}\text { Butir } \\
\text { Pernyataan 5 }\end{array}$ & 0.394 & 0.268 & Valid \\
\hline $\mathbf{6}$ & $\begin{array}{c}\text { Butir } \\
\text { Pernyataan 6 }\end{array}$ & 0.401 & 0.268 & Valid \\
\hline $\mathbf{7}$ & $\begin{array}{c}\text { Butir } \\
\text { Pernyataan 7 }\end{array}$ & 0.313 & 0.268 & Valid \\
\hline $\mathbf{8}$ & $\begin{array}{c}\text { Butir } \\
\text { Pernyataan 8 }\end{array}$ & 0.684 & 0.268 & Valid \\
\hline $\mathbf{9}$ & $\begin{array}{c}\text { Butir } \\
\text { Pernyataan 9 }\end{array}$ & 0.406 & 0.268 & Valid \\
\hline $\mathbf{1 0}$ & $\begin{array}{c}\text { Butir } \\
\text { Pernyataan } \\
10\end{array}$ & 0.497 & 0.268 & Valid \\
\hline
\end{tabular}

Sumber : Data diolah 2017

Dari data tabeldiatas, dapat dilihat bahwa 10 butir pernyataan variabel kepemimpinan $\left(\mathrm{X}_{1}\right)$ semua butir pernyataan dinayatakan valid, dimana semua item-item pernyataan memiliki nilai corrected item total correlation lebih besar dari 0.268 .

\section{Pengujian Validitas Variabel Budaya Organisasi $\left(\mathbf{X}_{2}\right)$}

Tabel 4.12

Uji Validitas Variabel Budaya Organisasi $\left(\mathbf{X}_{2}\right)$

\begin{tabular}{|c|c|c|c|c|}
\hline No & Pernyataan & $\begin{array}{c}\mathbf{r} \\
\text { hitung }\end{array}$ & $\begin{array}{c}\mathbf{r} \\
\text { tabel }\end{array}$ & $\begin{array}{l}\text { Ket. } \\
\text { Butir }\end{array}$ \\
\hline 1 & $\begin{array}{c}\text { Butir } \\
\text { Pernyataan } \\
1\end{array}$ & 0.356 & 0.268 & Valid \\
\hline 2 & $\begin{array}{c}\text { Butir } \\
\text { Pernyataan } \\
2\end{array}$ & 0.542 & 0.268 & Valid \\
\hline 3 & $\begin{array}{c}\text { Butir } \\
\text { Pernyataan } \\
3\end{array}$ & 0.311 & 0.268 & Valid \\
\hline 4 & $\begin{array}{c}\text { Butir } \\
\text { Pernyataan } \\
4\end{array}$ & 0.626 & 0.268 & Valid \\
\hline 5 & $\begin{array}{c}\text { Butir } \\
\text { Pernyataan } \\
5\end{array}$ & 0.454 & 0.268 & Valid \\
\hline 6 & $\begin{array}{c}\text { Butir } \\
\text { Pernyataan } \\
6\end{array}$ & 0.447 & 0.268 & Valid \\
\hline 7 & $\begin{array}{c}\text { Butir } \\
\text { Pernyataan } \\
7\end{array}$ & 0.678 & 0.268 & Valid \\
\hline 8 & $\begin{array}{c}\text { Butir } \\
\text { Pernyataan } \\
8\end{array}$ & 0.630 & 0.268 & Valid \\
\hline 9 & $\begin{array}{c}\text { Butir } \\
\text { Pernyataan } \\
9\end{array}$ & 0.646 & 0.268 & Valid \\
\hline
\end{tabular}

\begin{tabular}{|c|c|c|c|c|}
\hline $\mathbf{1 0}$ & $\begin{array}{c}\text { Butir } \\
\text { Pernyataan } \\
10\end{array}$ & 0.437 & 0.268 & Valid \\
\hline $\mathbf{1 1}$ & $\begin{array}{c}\text { Butir } \\
\text { Pernyataan } \\
11\end{array}$ & 0.430 & 0.268 & Valid \\
\hline $\mathbf{1 2}$ & $\begin{array}{c}\text { Butir } \\
\text { Pernyataan } \\
12\end{array}$ & 0.387 & 0.268 & Valid \\
\hline $\mathbf{1 3}$ & $\begin{array}{c}\text { Butir } \\
\text { Pernyataan } \\
13\end{array}$ & 0.479 & 0.268 & Valid \\
\hline $\mathbf{1 4}$ & $\begin{array}{c}\text { Butir } \\
\text { Pernyataan } \\
14\end{array}$ & 0.631 & 0.268 & Valid \\
\hline
\end{tabular}

Sumber : Data diolah 2017

Dari data tabel diatas, dapat dilihat bahwa dari 14 butir pernyataan variabel budaya organisasi $\left(\mathrm{X}_{2}\right)$ semua butir pernyataan dinyatakan valid, dimana semua item-item pernyataan memiliki nilai corrected item total correlation lebih besar dari 0.268 .

Tabel 4.13

Uji Validitas Variabel Kinerja

\begin{tabular}{|c|c|c|c|c|}
\hline $\begin{array}{l}\mathbf{N} \\
\mathbf{o}\end{array}$ & $\begin{array}{c}\text { Pernyataa } \\
\mathbf{n}\end{array}$ & $\begin{array}{c}\mathbf{r} \\
\text { hitun } \\
\mathbf{g}\end{array}$ & $\begin{array}{c}r \\
\text { tabel }\end{array}$ & $\begin{array}{c}\text { Ket. } \\
\text { Buti } \\
\text { r }\end{array}$ \\
\hline 1 & $\begin{array}{c}\text { Butir } \\
\text { Pernyataan } \\
1\end{array}$ & 0.316 & $\begin{array}{c}0.26 \\
8\end{array}$ & $\begin{array}{c}\text { Vali } \\
\text { d }\end{array}$ \\
\hline 2 & $\begin{array}{c}\text { Butir } \\
\text { Pernyataan } \\
2\end{array}$ & 0.608 & $\begin{array}{c}0.26 \\
8\end{array}$ & $\begin{array}{c}\text { Vali } \\
\mathrm{d}\end{array}$ \\
\hline 3 & $\begin{array}{c}\text { Butir } \\
\text { Pernyataan } \\
3\end{array}$ & 0.363 & $\begin{array}{c}0.26 \\
8\end{array}$ & $\begin{array}{c}\text { Vali } \\
\mathrm{d}\end{array}$ \\
\hline 4 & $\begin{array}{c}\text { Butir } \\
\text { Pernyataan } \\
4\end{array}$ & 0.628 & $\begin{array}{c}0.26 \\
8\end{array}$ & $\begin{array}{c}\text { Vali } \\
\mathrm{d}\end{array}$ \\
\hline 5 & $\begin{array}{c}\text { Butir } \\
\text { Pernyataan } \\
5\end{array}$ & 0.499 & $\begin{array}{c}0.26 \\
8\end{array}$ & $\begin{array}{c}\text { Vali } \\
\mathrm{d}\end{array}$ \\
\hline 6 & $\begin{array}{c}\text { Butir } \\
\text { Pernyataan } \\
6\end{array}$ & 0.388 & $\begin{array}{c}0.26 \\
8\end{array}$ & $\begin{array}{c}\text { Vali } \\
\mathrm{d}\end{array}$ \\
\hline 7 & $\begin{array}{c}\text { Butir } \\
\text { Pernyataan } \\
7 \\
\end{array}$ & 0.617 & $\begin{array}{c}0.26 \\
8\end{array}$ & $\begin{array}{c}\text { Vali } \\
\mathrm{d}\end{array}$ \\
\hline 8 & $\begin{array}{c}\text { Butir } \\
\text { Pernyataan } \\
8 \\
\end{array}$ & 0.308 & $\begin{array}{c}0.26 \\
8\end{array}$ & $\begin{array}{c}\text { Vali } \\
\text { d }\end{array}$ \\
\hline 9 & $\begin{array}{c}\text { Butir } \\
\text { Pernyataan } \\
9\end{array}$ & 0.352 & $\begin{array}{c}0.26 \\
8\end{array}$ & $\begin{array}{c}\text { Vali } \\
\mathrm{d}\end{array}$ \\
\hline 10 & $\begin{array}{c}\text { Butir } \\
\text { Pernyataan } \\
10 \\
\end{array}$ & 0.456 & $\begin{array}{c}0.26 \\
8\end{array}$ & $\begin{array}{c}\text { Vali } \\
\mathrm{d}\end{array}$ \\
\hline 11 & $\begin{array}{c}\text { Butir } \\
\text { Pernyataan } \\
11\end{array}$ & 0.452 & $\begin{array}{c}0.26 \\
8\end{array}$ & $\begin{array}{c}\text { Vali } \\
\mathrm{d}\end{array}$ \\
\hline 12 & $\begin{array}{c}\text { Butir } \\
\text { Pernyataan } \\
12 \\
\end{array}$ & 0.584 & $\begin{array}{c}0.26 \\
8\end{array}$ & $\begin{array}{c}\text { Vali } \\
\mathrm{d}\end{array}$ \\
\hline 13 & $\begin{array}{c}\text { Butir } \\
\text { Pernyataan } \\
13 \\
\end{array}$ & 0.320 & $\begin{array}{c}0.26 \\
8\end{array}$ & $\begin{array}{c}\text { Vali } \\
\text { d }\end{array}$ \\
\hline 14 & $\begin{array}{c}\text { Butir } \\
\text { Pernyataan }\end{array}$ & 0.611 & $\begin{array}{c}0.26 \\
8 \\
\end{array}$ & $\begin{array}{c}\text { Vali } \\
\text { d }\end{array}$ \\
\hline
\end{tabular}




\begin{tabular}{|c|c|c|c|c|}
\hline $\mathbf{1 5}$ & 14 & & & \\
\hline $\begin{array}{c}\text { Putir } \\
\text { Pernyaan } \\
15\end{array}$ & 0.508 & $\begin{array}{c}0.26 \\
8\end{array}$ & $\begin{array}{c}\text { Vali } \\
\mathrm{d}\end{array}$ \\
\hline $\mathbf{1 6}$ & $\begin{array}{c}\text { Butir } \\
\text { Pernyataan } \\
16\end{array}$ & 0.368 & $\begin{array}{c}0.26 \\
8\end{array}$ & $\begin{array}{c}\text { Vali } \\
\mathrm{d}\end{array}$ \\
\hline
\end{tabular}

Sumber : Data diolah 2017

Dari data tabel diatas, dapat dilihat bahwa dari 16 butir pernyataan variabel kinerja (Y) semua butir pernyataan dinyatakan valid, dimana semua item-item pernyataan memiliki niai corrected item total correlation lebih besar dari 0.268.

\section{B. Uji Reliabilitas}

Suatu kuesioner dikatakan reliabel atau handal jika jawaban responden terhadap pernyataan adalah konsisten atau stabil dari waktu ke waktu (Sugiyono, 2014:183).Uji reabilitas adalah tingkat kestabilan suatu alat pengukur dalam waktu suatu gejala.

Kriteria untuk mengolah uji realibilita adalah sebagai berikut :

1) Jika nilai Cronbach Alpha $>\mathrm{r}_{\text {tabel }}$ dan nilai $r$ positif, maka butir pernyataan dikatakan reliabel.

2) Jika nilai Cronbach Alpha $<\mathrm{r}_{\text {tabel }}$ dan nilai $r$ negatif, maka butir pernyataan dikatakan tidak reliabel.

3) Jika nilai Cronbach Alpha $<$ Sandard Cronbach Alpha0,60, maka butir pernyataan dikatakan tidak reliabel.

4) Jika nilai Cronbach Alpha $<$ Standard Cronbach Alpha0,60, maka butir pernyataan dikatakan reliabel.

Adapun nilai $\mathrm{r}_{\text {tabel }}$ untuk 54 responden dengan taraf signifikansi $\alpha=0,05(5 \%)$ artinya tingkat kepercayaan pengujiannya adalah 95\%. Hasil uji reliabilitas dalam penelitian ini dilakukan dengan menggunakan program SPSS Versi 22, hasilnya sebagai berikut :

Tabel 4.14

Hasil Uji Realibilitas Data

\begin{tabular}{|c|c|c|c|c|}
\hline $\begin{array}{c}\text { No } \\
\cdot\end{array}$ & Variabel & $\begin{array}{c}\mathbf{r} \\
\text { hitun } \\
\text { g }\end{array}$ & $\begin{array}{c}\mathbf{r} \\
\text { tabe } \\
\text { l }\end{array}$ & $\begin{array}{c}\text { Kesimpul } \\
\text { an }\end{array}$ \\
\hline 1 & $\begin{array}{c}\text { Kepemimpin } \\
\text { an (X1) }\end{array}$ & $\mathbf{0 . 5 6 1}$ & $\begin{array}{c}\mathbf{0 . 2 6} \\
8\end{array}$ & Reliabel \\
\hline 2 & $\begin{array}{c}\text { Budaya } \\
\text { Organisasi } \\
\text { (X2) }\end{array}$ & $\mathbf{0 . 7 7 5}$ & $\begin{array}{c}\mathbf{0 . 2 6} \\
8\end{array}$ & Reliabel \\
\hline 3 & Kinerja & $\mathbf{0 . 7 5 3}$ & $\mathbf{0 . 2 6}$ & Reliabel \\
\hline
\end{tabular}

\begin{tabular}{|c|c|c|l|}
\hline & & $\mathbf{8}$ & \\
\hline
\end{tabular} SPSS versi 22

Berdasarkan hasil uji reliabilitas pada tabel diatas, dapat diketahui bahwa seluruh variabel yang digunakan dinyatakan reliablel, karena $r$ hitung lebih besar dari $r$ tabel.

\section{Uji Asumsi Klasik (Uji Prasyarat)}

\section{1) Uji Normalitas}

Uji normalitas bertujuan untuk menguji apakah dalam model regresi, variabel dependen dan variabel independen berdistribusi normal atau berdistribusi tidak normal.Model regresi yang baik adalah distribusi data normal atau uji normalitas untuk memastikan asumsi bahwa persamaan tersebut berdistribusi normal, Pengujian ini dilakukan dengan mengamati histogram atas nilai residual dan grafik normal probability plot. Deteksi pengambilan keputusan adalah dengan syarat penyebaran titik-titik residual mengikuti arah garis diagonal. Adapun hasil uji normalitas diolah dengan SPSS versi 22 , dibawah ini :

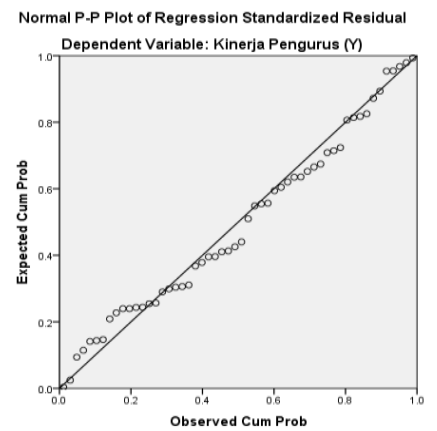

Sumber : Data Primer, tahun 2017 diolah dengan SPSS versi 22

Gambar 4.1P-P Plot Uji Normalitas - Diagram Penyebaran Titik Residual

Pada gambar grafik diatas dapat dilihat bahwa grafik normal probability plot menunjukkan pola grafik yang normal. Hal ini terlihat dari titik-titik yang menyebar disekitar grafik normal.Hal ini terlihat dari titik-titik yang menyebar disekitar garis diagonal dan penyebarannya mengikuti garis diagonal. 
Dengan penyebaran yang mengikuti alur garis diagonal tersebut maka dapat disimpulkan bahwa model regresi layak dipakai karena memenuhi asumsi normalitas.

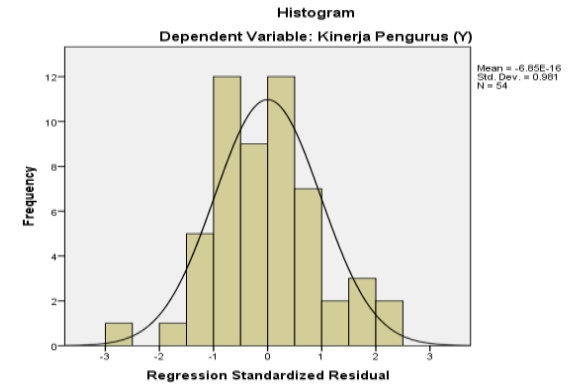

Sumber : Data Primer, tahun 2017, diolah dengan SPSS versi 22

Gambar 4.2Histogram Uji Normalitas Data

Pada gambar diatas dapat dilihat bahwa grafik histogram yang memberikan pola distribusi yang normal (tidak terjadi kemencengan).Kedua grafik diatas menunjukkan bahwa model regresi layak dipakai karena memiliki asumsi normalitas.

\section{2) Uji Heteroskedastisitas}

Uji heteroskedastisitas dilakukan dengan tujuan untuk menguji apakah dalam sebuah model regresi terjadi ketidaksamaan varians residual dari suatu pengamatan ke pengamatan yang lain tetap. Salah satu caraatau teknik untuk mendeteksi telah terjadi heteroskedastisitas atau tidak adalah dengan melihat grafik scatter plotdimana antara nilai prediksi variabel terikat (ZPRED) dan nilai residualnya (SRESID).

Jika titik-titik pada gambar yang dihasilkan membentuk pola tertentu yang teratur seperti gelombang besar melebar, kemudian menyempit maka telah terjadi heteroskedastisitas.Namun jika titik-titik menyebar diatas dan dibawah angka 0 pada sumbu $\mathrm{Y}$ tanpa membentuk pola tertentu, maka model tersebut tidak terjadi heteroskedastisitas.

Adapun hasil uji heteroskedastisitas dalam penelitian ini diolah dengan menggunakan program SPSS versi 22 yang hasilnya dapat dilihat pada gambar berikut ini :

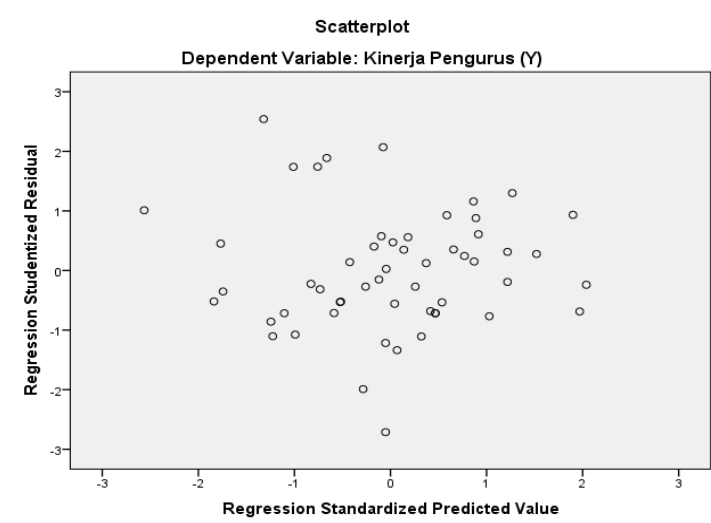

Sumber : Data Primer, tahun 2017, diolah dengan SPSS versi 22

Gambar 4.3 Hasil Uji Heteroskedastisitas

Pada gambar diatas dapat dilihat bahwa titik-titik pada grafik scatter plottidakmempunyai pola penyebaran yang jelas dan titik-titik tersebut menyebar di atas dandibawah angka 0 pada sumbu $Y$, dengan demikian hal ini menunjukkan bahwa tidak terdapat gangguan heteroskedastisitas.

\section{3) Uji Multikolinearitas}

Uji multikolinearitas bertujuan untuk menguji apakah model regresi ditemukan adanya korelasi antar variabel independen.Model regresi yang baik seharusnya tidak terjadi korelasi di antara variabel independen. Untuk mendeteksi ada tidaknya multikolinearitas dalam model regrsi dapat dilihat dari tolerance value atau Variance Inflation Factor (VIP)dengan ketentuan sebagai berikut :

a) Jika nilai VIF diatas nilai 10 atau tolerance value dibawah 0,10 maka terjadi multikolinearitas.

b) Jika nilai VIF dibawah nilai 10 atau tolerance value diatas 0,10 maka tidak terjadi multikolinearitas.

Hasil uji multikolinearitas dilakukan dengan menggunakan SPSS Versi 22 dengan hasil sebagai berikut :

Tabel 4.15

Hasil Uji Multikoliniearitas Dengan Kinerja (Y) Sebagai Variabel Dependen Coefficients

\begin{tabular}{|c|c|c|c|c|c|}
\hline Model & $\begin{array}{c}\text { Unstandar } \\
\text { dized } \\
\text { Coefficien } \\
\text { ts }\end{array}$ & $\begin{array}{c}\text { Standar } \\
\text { dized } \\
\text { Coeffici } \\
\text { ents }\end{array}$ & $\mathrm{T}$ & $\begin{array}{l}\mathrm{Si} \\
\mathrm{g} .\end{array}$ & $\begin{array}{l}\text { Collinearity } \\
\text { Statistics }\end{array}$ \\
\hline
\end{tabular}




\begin{tabular}{|c|c|c|c|c|c|c|c|}
\hline & B & $\begin{array}{l}\text { Std. } \\
\text { Err } \\
\text { or }\end{array}$ & Beta & & & $\begin{array}{c}\text { Tolera } \\
\text { nce }\end{array}$ & $\begin{array}{l}\text { VI } \\
\text { F }\end{array}$ \\
\hline (Constant) & $\begin{array}{c}15.2 \\
93\end{array}$ & $\begin{array}{l}7.5 \\
27\end{array}$ & & $\begin{array}{l}2.0 \\
32\end{array}$ & $\begin{array}{l}.0 \\
47\end{array}$ & & \\
\hline \begin{tabular}{cc}
\multicolumn{3}{c}{ Kepemim } \\
1 & pinan \\
& (X1)
\end{tabular} & .364 & $\begin{array}{c}.17 \\
6\end{array}$ & .223 & $\begin{array}{c}2.0 \\
70\end{array}$ & $\begin{array}{l}.0 \\
44\end{array}$ & .871 & $\begin{array}{l}1.1 \\
48\end{array}$ \\
\hline $\begin{array}{c}\text { Budaya } \\
\text { Organisas } \\
\text { i (X2) }\end{array}$ & .632 & $\begin{array}{c}.11 \\
7\end{array}$ & .584 & $\begin{array}{l}5.4 \\
17\end{array}$ & $\begin{array}{l}.0 \\
00\end{array}$ & .871 & $\begin{array}{l}1.1 \\
48\end{array}$ \\
\hline
\end{tabular}

Sumber : Data Primer, tahun 2017, diolah dengan SPSS versi 22

Pada tabel diatas, memperlihatkan bahwa nilai Variance Inflation Factor (VIF) untuk variabel Kepemimpinan $\left(\mathrm{X}_{1}\right)$ diperoleh sebesar 1.148 dan Budaya Organisasi $\left(\mathrm{X}_{2}\right)$ diperoleh sebesar 1.148 dimana masing-masing nilai tolerancevariabel bebas kurang dari 1 dan nilai VIF kurang dari 10, dengan demikian model regresi ini tidak terjadi korelasi antar variabel independen didalam persamaan itu sendiri atau tidak ada multikolinearitas.

\section{4) Uji Autokorelasi}

Uji autkorelasi digunakan untuk mengetahui ada atau tidaknya penyimpangan korelasi antar anggota sampel. Untuk mengetahui adanya autokorelasi dilakukan pengujian DurbinWatson (DW). Untuk mengetahui ada tidaknya autokorelasi Uji Durbin Watson(DW test) berikut ini kriteria yang menajdi acuannya :

Tabel 4.16

Pedoman Interpretasi Uji Durbin-Watson

\begin{tabular}{|c|c|}
\hline Kriteria & Keterangan \\
\hline$<1$ & Ada autokorealsi \\
\hline $1,1-1,54$ & Tanpa kesimpulan \\
\hline $1,55-2,46$ & $\begin{array}{c}\text { Tidak ada } \\
\text { autokrelasi }\end{array}$ \\
\hline $2,46-2,9$ & Tanpa kesimpulan \\
\hline$>2,9$ & Ada autokorelasi \\
\hline
\end{tabular}

Sumber : Algifari (2010:88)

Berikut ini hasil uji autokorelasi dengan uji Durbin-Watson yang diolah dengan SPSS versi 22, sebagai berikut :

Tabel 4.17

Uji Durbin-Watson Model Summary ${ }^{\mathrm{b}}$

\begin{tabular}{|c|c|c|c|c|c|}
\hline $\begin{array}{c}\text { Mod } \\
\text { el }\end{array}$ & $\mathrm{R}$ & $\begin{array}{c}\mathrm{R} \\
\text { Squa } \\
\text { re }\end{array}$ & $\begin{array}{c}\text { Adjust } \\
\text { ed R } \\
\text { Square }\end{array}$ & $\begin{array}{c}\text { Std. } \\
\text { Error } \\
\text { of the } \\
\text { Estima } \\
\text { te }\end{array}$ & $\begin{array}{c}\text { Durbi } \\
\mathrm{n}- \\
\text { Watso } \\
\mathrm{n}\end{array}$ \\
\hline 1 & $\begin{array}{c}.69 \\
6^{\mathrm{a}}\end{array}$ & .484 & .464 & 4.051 & 1.692 \\
\hline
\end{tabular}

a. Predictors: (Constant), Budaya Organisasi (X2), Kepemimpinan (X1)

b. Dependent Variable: Kinerja (Y)

Sumber : Data Primer, tahun 2017 yang telah diolah dengan SPSS Versi 22

Dari tabel diatas, diperoleh nilai Durbin-Watson sebesar 1.692 dan berada diantara $(1,550$ - 2,460) sesuai dengan ketentuan maka model regresi ini tidak ada autokorelasi.

\section{Analisis Regresi Linear Beganda}

Uji regresi berganda ini dimaksudkan untuk mengetahui seberapa besar pengaruh variabel $\mathrm{X}_{1}, \mathrm{X}_{2}$, dan $\mathrm{Y}$. Dalam penelitian ini adalah kepemimpinan $\left(\mathrm{X}_{1}\right)$ dan budaya organisasi $\left(\mathrm{X}_{2}\right)$ serta kinerja $(\mathrm{Y})$.

Berikut ini hasil olahan data regresi dengan SPSS versi 22 yang dapat dilihat pada tabel berikut ini :

Tabel 4.18

Hasil Pengolahan Regresi Berganda Variabel Kepemimpinan $\left(\mathrm{X}_{1}\right)$ dan Budaya Organisasi $\left(\mathbf{X}_{2}\right)$

Coefficients $^{\mathrm{a}}$

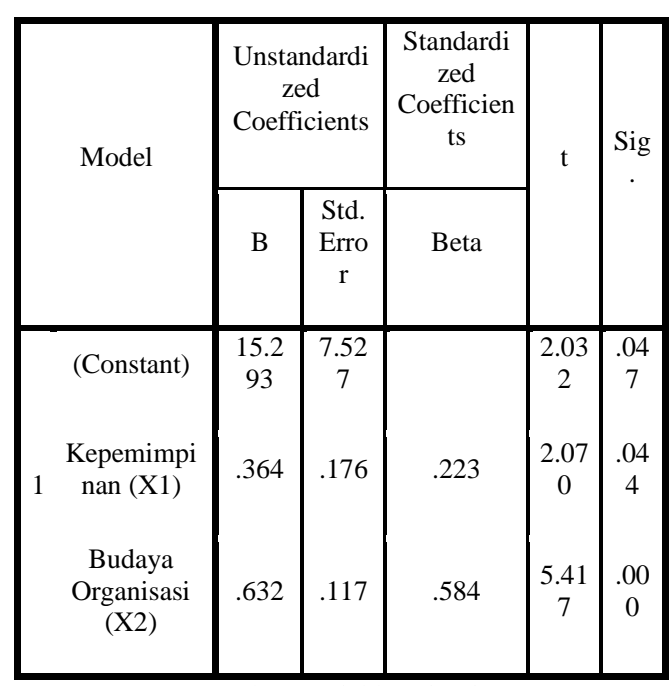

a. Dependent Variable: Kinerja (Y)

Sumber : Data Primer tahun 2017, diolah dengan SPSS Versi 22. 
Berdasarkan hasil perhitungan regresi pada tabel diatas, diperoleh persamaan dengan regresinya $\mathrm{Y}=15.293+0.364 \mathrm{X}_{1}+$ $0.632 \mathrm{X}_{2}$. Dari persamaan di atas maka dapat disimpulkan sebagai berikut:

$\begin{aligned} 15.293= & \text { Jika kepemimpinan }\left(\mathrm{X}_{1}\right) \text { dan } \\ & \text { budaya organisasi }\left(\mathrm{X}_{2}\right)=0 \\ & \text { atau konstan, maka kinerja } \\ & \text { akan bernilai 15.293. } \\ 0.364= & \text { Jika kepemimpinan }\left(\mathrm{X}_{1}\right) \\ & \text { mengalami peningkatan } \\ & \text { sebesar satu satuan, dan } \\ & \text { budaya organisasi }\left(\mathrm{X}_{2}\right) \text { tetap } \\ & \text { atau konstan, maka kinerja } \\ & \text { (Y) hanya akan mengalami } \\ & \text { peningkatan score sebesar } \\ & \text { 0.364. }\end{aligned}$

$0.632=$ Jika budaya organisasi $\left(\mathrm{X}_{2}\right)$ mengalami peningkatan sebesar satu satuan, dan kepemimpinan $\left(\mathrm{X}_{1}\right)$ tetap atau konstan, maka kinerja (Y) akan mengalami peningkatan score sebesar 0,632 .

\section{E. Pengaruh Secara Parsial}

Untuk mengetahui variabel kepemimpinan $\left(\mathrm{X}_{1}\right)$ terhadap kinerja $(\mathrm{Y})$ serta variabel budaya organisasi $\left(\mathrm{X}_{2}\right)$ terhadap kinerja secara parsial digunakan analisis koefisien determinasi. Adapun tingkat hubungan secara parsial tersebut hasil analisinya sebagai berikut :

Tabel 4.19

Pengaruh Secara Parsial Variabel

Kepemimpinan $\left(\mathbf{X}_{1}\right)$ Terhadap Kinerja $(\mathbf{Y})$

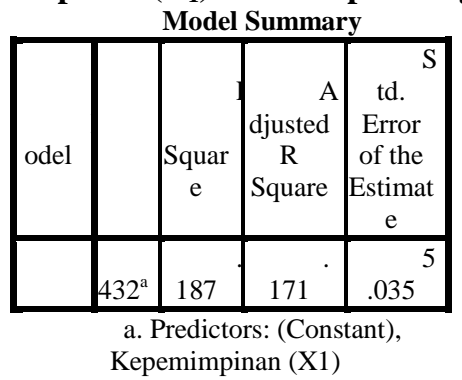

Sumber : Data Primer, tahun 2017, diolah dengan SPSS Versi 22

Dari tabel diatas, diperoleh nilai koefisien determinasi sebesar 0.187 maka dapat disimpulkan bahwa variabel Kepemimpinan $\left(\mathrm{X}_{1}\right)$ berpengaruh terhadap variabel Kinerja Karyawan (Y) sebesar
$18.7 \%$ sedangkan sisanya $81.3 \%$ dipengaruhi oleh faktor-faktor lain.

Selanjutnya pengaruh variabel budaya organisasi $\left(\mathrm{X}_{2}\right)$ terhadap kinerja $(\mathrm{Y})$ secara parsial, hasil analisisnya sebagai berikut:

Tabel 4.20

Pengaruh Secara Parsial Variabel Budaya Organisasi $\left(\mathbf{X}_{2}\right)$ Terhadap Kinerja $(\mathbf{Y})$

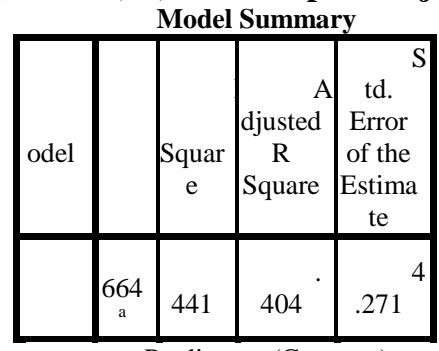

a. Predictors: (Constant)

Budaya Organisasi (X2)

Sumber: Data Primer tahun 2017, diolah dengan SPSS Versi 22.

Dari tabel diatas, diperoleh nilai koefisien determinasi sebesar 0.441 maka dapat disimpulkan bahwa variabel budaya organisasi $\left(\mathrm{X}_{2}\right)$ berpengaruh terhadap variabel kinerja (Y) sebesar 44,1\% sedangkan sisanya $55.9 \%$ dipengaruhi oleh faktor-faktor lain.

\section{F. Analisis Koefisien Determinasi \\ Koefisien Determinasi (Kd)}

dipergunakan untuk mengetahui seberapa besar tingkat hubungan atau pengaruh antara variabel kepemimpinan dan budaya organisasi terhadap kinerja.

Adapun cara mengetahui tingkat hubungan tersebut dipergunakan rumus sebagai berikut : $\mathrm{KD}=\mathrm{R}^{2}$ x $100 \%$ yang diolah dengan program SPSS versi 22 , terlihat pada tabel bawah ini:

Tabel 4.21

Hasil Pengolahan Data Koefisien Determinasi Variabel Kepemimpinan (X1) dan Budaya Organisasi (X2)

\begin{tabular}{|c|c|c|c|c|}
\hline \multicolumn{5}{|c|}{ Model Summary } \\
\hline $\begin{array}{l}\text { Mod } \\
\text { el }\end{array}$ & $\mathrm{R}$ & $\begin{array}{l}\text { R } \\
\text { Squa } \\
\text { re }\end{array}$ & $\begin{array}{l}\text { Adjust } \\
\text { ed R } \\
\text { Square }\end{array}$ & $\begin{array}{l}\text { Std. } \\
\text { Error } \\
\text { of the } \\
\text { Estima } \\
\text { te }\end{array}$ \\
\hline 1 & $\begin{array}{r}.69 \\
6^{\mathrm{a}}\end{array}$ & .484 & .464 & 4.051 \\
\hline
\end{tabular}

Dari tabel diatas, diperoleh nilai koefisien determinasi sebesar 0,484 maka dapat disimpulkan bahwa variabel 
kepemimpinan $\left(\mathrm{X}_{1}\right)$ dan budaya organisasi $\left(\mathrm{X}_{2}\right)$ berpengaruh terhadap variabel kinerja (Y) sebesar $48.4 \%$ sedangkan sisanya $51.6 \%$ dipengaruhi oleh faktor-faktor lain yang tidak diteliti dalam penelitian ini.

\section{G. Pengujian Hipotesis}

1) Uji Parsial (t hitung)

Untuk pengujian pengaruh antara variabel kepemimpinan $\left(\mathrm{X}_{1}\right)$ dan budaya organisasi $\left(\mathrm{X}_{2}\right)$ terhadap kinerja dapat dilakukan dengan uji statistik t (uji secara parsial).

Dalam penelitian ini digunakan kriteria signifikansi $5 \% \quad(0,05)$ dengan membandingkan $\mathrm{t}_{\text {hitung }}$ dengan $\mathrm{t}_{\text {tabel }}$ yaitu sebagai berikut :

a) Jika $t_{\text {hitung }}<t_{\text {tabel }}$ : berarti $\mathrm{H}_{0}$ diterima dan $\mathrm{H}_{1}$ ditolak $(\alpha=5 \%)$

b) Jika $t$ hitung $>t t_{\text {abel }}$ : berarti $\mathrm{H}_{0}$ ditolak dan $\mathrm{H}_{1}$ diterima $(\alpha=5 \%)$

Adapun untuk menentukan besarnya $\mathrm{t}$ tabel dicari dengan menggunakan rumus berikut ini :

$t_{\text {tabel }}=$ ta.df $($ Taraf Alpha $\mathrm{x}$ Degree of Freedom)

$$
\begin{array}{ll}
\alpha & =\text { tarif nyata } 5 \% \\
\mathrm{df} & =(\mathrm{n}-2), \text { maka diperoleh }(54-2)= \\
& 52 \\
t_{\text {tabel }}= & 1.674
\end{array}
$$

\section{a) Pengaruh Kepemimpinan $\left(\mathbf{X}_{1}\right)$ Terhadap Kinerja (Y)}

Menentukan rumusan hipotesisnya adalah :

$\mathrm{H}_{0}: \beta=0$ Tidak terdapat pengaruh antara kepemimpinan terhadap kinerja secara parsial.

$\mathrm{H}_{0}: \beta \neq 0$ Terdapat pengaruh antara kepemimpinan terhadap kinerja secara parsial

Adapun hasil pengolahan data menggunakan program SPSS versi 22, dengan hasil sebagai berikut :

Tabel 4.22

Hasil uji t Variabel Kepemimpinan (X1) Coefficients $^{\mathrm{a}}$

\begin{tabular}{|l|c|c|c|c|}
\hline Model & $\begin{array}{c}\text { Unstandar } \\
\text { dized } \\
\text { Coefficien } \\
\text { ts }\end{array}$ & $\begin{array}{c}\text { Standard } \\
\text { ized } \\
\text { Coeffici } \\
\text { ents }\end{array}$ & $\mathrm{T}$ & $\begin{array}{c}\text { Si } \\
\text { g. }\end{array}$ \\
\hline
\end{tabular}

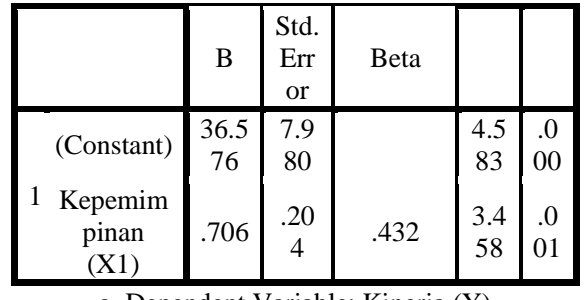

a. Dependent Variable: Kinerja (Y)

Sumber : Data Primer tahun 2017, diolah dengan SPSS Versi 22

Dari tabel diatas diperoleh nilai $t$ hitung $>t_{\text {tabel }}(3.458>1.674)$, untuk itu $\mathrm{H}_{0}$ ditolak dan $\mathrm{H}_{1}$ diterima, hal ini menunjukkan bahwa terdapat pengaruh yang positif dan signifikan secara parsial antara kepemimpinan terhadap kinerja.

\section{b) Pengaruh Budaya Organisasi $\left(\mathbf{X}_{2}\right)$ Terhadap Kinerja (Y)}

Menentukan rumusan hipotesisnya adalah :

$\mathrm{H}_{0}: \beta=0$ Tidak terdapat pengaruh antara budaya organisasi terhadap kinerja secara parsial.

$\mathrm{H}_{0}: \beta \neq 0$ Terdapat pengaruh antara budaya organisasi terhadap kinerja secara parsial.

Adapun hasil pengolahan data menggunakan program SPSS Versi 22, dengan hasil sebagai berikut :

\begin{tabular}{|c|c|c|c|c|c|}
\hline \multirow[t]{2}{*}{ Model } & \multicolumn{2}{|c|}{$\begin{array}{c}\text { Unstandard } \\
\text { ized } \\
\text { Coefficient } \\
\mathrm{s} \\
\end{array}$} & \multirow{2}{*}{\begin{tabular}{|c}
$\begin{array}{c}\text { Standard } \\
\text { ized } \\
\text { Coefficie } \\
\text { nts }\end{array}$ \\
Beta
\end{tabular}} & \multirow[t]{2}{*}{$\mathrm{T}$} & $\mathrm{Si}$ \\
\hline & B & $\begin{array}{c}\text { Std. } \\
\text { Erro } \\
r\end{array}$ & & & \\
\hline $\begin{array}{c}\text { (Const } \\
\text { ant) } \\
1 \text { Budaya } \\
\text { Organi } \\
\text { sasi } \\
\text { (X2) }\end{array}$ & $\begin{array}{c}24.7 \\
35\end{array}$ & $\begin{array}{c}6.17 \\
3\end{array}$ & .664 & $\begin{array}{c}4.0 \\
07 \\
6.3 \\
99\end{array}$ & $\begin{array}{c}.0 \\
00\end{array}$ \\
\hline
\end{tabular}

Tabel 4.23

Hasil Uji t Variabel Budaya Organisasi $\left(\mathbf{X}_{2}\right)$ Coefficients $^{\mathrm{a}}$

Sumber : Data Primer tahun 2016, diolah dengan SPSS Versi 22.

Dari tabel diatas diperoleh nilai $t$ hitung $>t_{\text {tabel }}(6.399>1.674)$, untuk itu $\mathrm{H}_{0}$ ditolak dan $\mathrm{H}_{1}$ diterima, hal ini menunjukkan bahwa terdapat pengaruh 
yang positif dan signifikan secara parsial antara budaya organisasi terhadap kinerja.

\section{2) Uji F (Simultan)}

Untuk pengujian pengaruh variabel kepemimpinan $\left(\mathrm{X}_{1}\right)$ dan Budaya Organisasi $\left(\mathrm{X}_{2}\right)$ secara simultan terhadap kinerja (Y) dapat dilakukan dengan uji statistik F (uji simultan).

Sebagai pembanding untuk melihat pengaruh signifikan, maka digunakan kriteria signifikan $5 \% \quad(0,05)$ dan membandingkan antara $F_{\text {hitung }}$ dengan $F$ tabel dengan ketentuan sebagai berikut :

a) Jika $\mathrm{F}$ hitung $<\mathrm{F}_{\text {tabel }}$ : berarti $\mathrm{H}_{0}$ diterima dan $\mathrm{H}_{1}$ ditolak $(\alpha=5 \%)$

b) Jika $\mathrm{F}_{\text {hitung }}>\mathrm{F}_{\text {tabel }}$ : berarti $\mathrm{H}_{0}$ ditolak dan $\mathrm{H}_{1}$ diterima $(\alpha=5 \%)$

Adapun untuk menentukan besarnya $F_{\text {tabel }}$ dicari dengan ketentuan : $\alpha$ tarif nyata $5 \%$, df $=(n-k-1)$, maka diperoleh $(54-2-1)=51, \quad F_{\text {tabel }}=3,180$

Adapun hasil pengolahan data pengujian $\mathrm{F}$ menggunakan program SPSS Versi 22, dengan hasil sebagai berikut :

Tabel 4.24

Hasil Pengolahan Data Pengujian F Simultan ANOVA $^{\mathrm{a}}$

\begin{tabular}{|c|c|c|c|c|c|}
\hline Model & $\begin{array}{c}\text { Sum of } \\
\text { Square } \\
\text { s }\end{array}$ & $\begin{array}{l}D \\
f\end{array}$ & $\begin{array}{c}\text { Mean } \\
\text { Squar } \\
\text { e }\end{array}$ & $\mathrm{F}$ & Sig. \\
\hline $\begin{array}{cc} & \begin{array}{c}\text { Regressi } \\
\text { on }\end{array} \\
1 & \text { Residual } \\
& \text { Total }\end{array}$ & $\begin{array}{c}784.79 \\
1 \\
836.91 \\
3 \\
1621.7 \\
04\end{array}$ & $\begin{array}{l}5 \\
1 \\
5 \\
3\end{array}$ & $\begin{array}{c}392.3 \\
96 \\
16.41 \\
0\end{array}$ & $\begin{array}{c}23.9 \\
12\end{array}$ & $\begin{array}{l}.00 \\
0^{\mathrm{b}}\end{array}$ \\
\hline
\end{tabular}

a. Dependent Variable: Kinerja (Y)

b. Predictors: (Constant), Budaya Organisasi (X2), Kepemimpinan (X1)

Sumber : Data Primer tahun 2017, diolah dengan SPSS Versi 22.

Dari tabel diatas, diperoleh nilai $\mathrm{F}$ hitung $=\quad 23.912>\quad 3,180 \quad$ atau $\left(F_{\text {hitung }}>F_{\text {tabel }}\right.$ ) sehingga $\mathrm{H}_{0}$ ditolak dan $\mathrm{H}_{1}$ diterima. Artinya terdapat pengaruh positif dan signifikan secara simultan antara kepemimpinan dan budaya organisasi terhadap kinerja.

\section{B. Pembahasan}

\section{Pengaruh Kepemimpinan Terhadap Kinerja}

Kepemimpinan adalah proses mempengaruhi, menggerakkan, mengarahkan, mendorong dan mengajak orang lain untuk bekerja sama dalam rangka mencapai tujuan organisasi. Kepemimpinan sangat diperlukan bila suatu organisasi ingin sukses.Para karyawan maupun anggota memerlukan kepemimpinan sebagai dasar motivasi eksternal dalam rangka pencapaian tujuan.Kemampuan pemimpin sebagai pengawas dalam kriteria baik karena pimpinan memantau pekerjaan karyawan dan mengevaluasi hasil pekerjaan karyawan secara berkala. Kebutuhan akan prestasi pemimpin sangat baik terutama pada saat memberikan pengarahan kepada karyawan pada saat bekerja sehingga dapat memacu karyawan menyelesaikan pekerjaan dengan baik.

Pimpinan memberikan saran dan nasehat teknis serta ide-ide atau gagasan kreatif pada karyawan yang menandakan bahwa kecerdasan pemimpin sangat baik.Ketegasan pimpinan dalam melaksanakan peraturan dalam kategori baik.Peraturan yang berlaku di Bank DKI Cabang Pembantu Pondok Labu - Jakarta Selatan dipatuhi dan dilaksanakan dengan baik.

Kepemimpinan memiliki pengaruh yang positif dan signifikan terhadap kinerja karyawan pada Bank DKI Cabang Pembantu Pondok Labu - Jakarta Selatan.. Hal ini dibuktikan dengan melihat jawaban responden dimana dari 10 indikator memperoleh rata-rata responden menyatakan setuju, hal ini terlihat dari jawaban responden yang menyatakan setuju dan angat setuju sebesar $(42.8 \%+$ $23.9 \%)=66.7 \%$. Hal ini menunjukkan bahwa pendapat responden mengenai kepemimpinan sudah baik.Untuk lebih baik lagi pemimpin perlu memiliki kompetensi, komunikasi yang baik serta lebih berani dalam menghadapi masalah organisasi.

Berdasarkan hasil statistik dapat diketahui bahwa pengaruh kepemimpinan $\left(\mathrm{X}_{1}\right)$ terhadap kinerja $(\mathrm{Y})$ adalahsebesar 0.187 atau sebesar $18.7 \%$ sedangkan sisanya $81.3 \%$ dipengaruhi oleh faktor- 
faktor lain.Hal ini menunjukkan bahwa kepemimpinan yang baik akan meningkatkan kinerja karyawan. Dari pengujian hipotesis diperolehnilai $t$ hitung $>$ t tabel $(3.458>1.674)$, sehingga $\mathrm{H}_{0}$ ditolak dan $\mathrm{H}_{1}$ diterima, artinya terdapat pengaruh yang positif dan signifikan secara parsial antara kepemimpinan terhadap kinerja karyawan.

Hasil penelitian ini konsiten dengan hasil penelitian yang dilakukan olehDwi Wahyu Wijayanti (2012) tentang Pengaruh Kepemimpinan Dan Motivasi Kerja Terhadap Kinerja Karyawan.Disimpulkan bahwa kepemimpinan berpengaruh positif dan signifikan terhadap kinerja karyawan. Sehingga semakin baik kepemimpinan yang tercipta semakin meningkat pula kinerja karyawan, dan demikian pula sebaliknya semakin buruk kepemimpinan maka kinerja karyawan juga semakin buruk dan ini sesuai dengan pendapat Suwatno dan Priansa (2011:159) yang mengatakan bahwa "Seorang pemimpin "merupakan apa yang pemimpin lakukan dalam proses memimpin kelompok dan mempengaruhinya untuk mencapai tujuan perusahaan".

\section{Pengaruh Budaya Organisasi Terhadap Kinerja}

Budaya organisasi adalah sehimpunan nilai, prinsip-prinsip, tradisi, dan cara-cara bekerja yang dianut bersama oleh para anggota organisasi dan mempengaruhi cara mereka bertindak.Hal ini dibuktikan dengan melihat jawaban responden dimana dari empat belas indikator memperoleh rata-rata responden yang menyatakan setuju dan sangat setuju sebesar $(47.6 \%+$ $22.1 \%)=69.7 \%$ Hal ini menunjukkan bahwa pendapat responden mengenai budaya organisasi sudah baik. Maka untuk lebih baik lagi organisasi harus lebih memperhatikan individu yang memiliki kemampuan bekerja yang sangat baik dengan memberikan kebebasan dalam bertindak dan pengambilan keputusan di dalam organisasi.
Berdasarkan hasil statistik dapat diketahui bahwa pengaruh budaya organisasi terhadap kinerja karyawan 0.441 atau sebesar $44,1 \%$ sedangkan sisanya $55.9 \%$ dipengaruhi oleh faktorfaktor lain.Hal ini menunjukkan bahwa budaya organisasi berpengaruh terhadap kinerja karyawan.Dari pengujian hipotesis diperoleh $\mathrm{t}$ hitung > $\mathrm{t}$ tabel atau (6.399 > 1.674), sehingga $\mathrm{H}_{0}$ ditolak dan $\mathrm{H}_{1}$ diterima artinya terdapat pengaruh yang positif dan signifikan secara parsial antara budaya organisasi terhadap kinerja karyawan.

Hasil penelitian ini konsisten dengan penelitian Dede Sumarni (2011) dimana dalam penelitiannya tentang Pengaruh Kepemimpinan dan Budaya Organisasi Terhadap Kinerja Karyawan menghasilkan kesimpulan bahwa budaya organisasi mempunyai pengaruh positif terhadap kinerja karyawan.Jika kepemimpinan dan budaya organisasi tinggi maka kinerja karyawan meningkat.

\section{Pengaruh Kepemimpinan dan Budaya Organsiasi Terhadap Kinerja}

Berdasarkan hasil penelitian, menunjukkan bahwa kepemimpinan dan budaya organisasi berpengaruh positif terhadap kinerja karyawan Bank DKI Cabang Pembantu Pondok Labu - Jakarta Selatan Indonesia dengan persamaan regresi $\mathrm{Y}=15.293+0.364 \mathrm{X}_{1}+0.632$ $\mathrm{X}_{2}$.Hasil analisis regresi menunjukkan koefisien kepemimpinan sebesar 0.364 bertanda positif dan budaya organisasi sebesar 0.632. Semakin baik kepemimpinan yang dijalankan maka akan semakin baik pula kinerja karyawan. Demikian pula sebaliknya, kepemimpinan yang dijalankan kurang baik maka kinerja juga akan mengalami penurunan. Demikian pula dengan budaya organisasi.Kontribusi pengaruh kepemimpinan dan budaya organisasi 
adalah sebesar $48.4 \%$ meskipun tergolong sedang namun positif.

Dari pengujian hipotesis menggunakan uji statistik $F_{\text {hitung }}=23.912$ $>3,180$ atau $\left(F_{\text {hitung }}>F_{\text {tabel }}\right)$ sehingga $\mathrm{H}_{0}$ ditolak dan $\mathrm{H}_{1}$ diterima. Artinya terdapat pengaruh positif dan signifikan secara simultan antara kepemimpinan dan budaya organisasi terhadap kinerja karyawan.

Hasil penelitian ini konsisten dengan hasil penelitian yang dilakukan olehHendriawan (2014), yang meneliti tentang Pengaruh Gaya Kepemimpinan Dan Budaya Organisasi Terhadap Kinerja Karyawan. Dalam penelitiannya menunjukkan bahwa terdapat pengaruh positif dan signifikan variabel gaya kepemimpinan dan budaya organisasi terhadap kinerja karyawan dan ini sesuai dengan pendapat Anwar Prabu Mangkunegara (2012:18) bahwa "Kinerja merupakan perbandingan antara hasil yang dicapai dengan peran serta tenaga kerja dalam persatuan".

\section{KESIMPULAN,DAN SARAN Kesimpulan}

Bedasarkan uraian pada bab-bab sebelumnya dan hasil analisis serta pembahasan, berikut keismpulannya :

1. Kepemimpinan memiliki pengaruh positif dan signifikan terhadap kinerja karyawan Bank DKI Cabang Pembantu Pondok Labu - Jakarta Selatan. Hal ini dibuktikan dengan melihat jawaban responden dimana dari 10 indikator memperoleh total rata-rata responden menyatakan setuju, hal ini terlihat dari jawaban responden yang menyatakan setuju dan sangat setuju sebesar $(42.8 \%$ $+23.9 \%)=66.7 \%$. Hal ini menunjukkan bahwa pendapat responden mengenai kepemimpinan sudah baik. Berdasarkan hasil statistik dapat diketahui bahwa pengaruh kepemimpinan $\left(\mathrm{X}_{1}\right)$ tehadap kinerja $(\mathrm{Y})$ adalah sebesar 0.187 atau sebesar
$18.7 \%$ sedangkan sisanya $81.3 \%$ dipengaruhi oleh faktor-faktor lain. Hal ini menunjukkan bahwa kepemimpinan yang baik akan meningkatkan kinerja karyawan. Dari pengujian hipotesis diperoleh nilai $\mathrm{t}$ hitung $>\mathrm{t}$ tabel $(3.458$ $>$ 1.674), sehingga $\mathrm{H}_{0}$ ditolak dan $\mathrm{H}_{1}$ diterima, artinya terdapat pengaruh yang positif dan signifikan secara parsial antara kepemimpinan terhadap kinerja karyawan.

2. Budaya organisasi memiliki pengaruh yang positif dan signifikan terhadap kinerja karyawan pada Bank DKI Cabang Pembantu Pondok Labu Jakarta Selatan. Hal ini dibuktikan dengan melihat jawaban responden dimana dari empat belas indikator memperoleh rata-rata responden yang menyatakan setuju dan sangat setuju sebesar $(47.6 \%+22.1 \%)=69.7 \%$ Hal ini menunjukkan bahwa pendapat responden mengenai budaya organisasi sudah baik. Berdasarkan hasil statistik dapat diketahui bahwa pengaruh budaya organisasi $\left(\mathrm{X}_{2}\right)$ tehadap kinerja (Y) adalah 0.441 atau sebesar $44,1 \%$ sedangkan sisanya $55.9 \%$ dipengaruhi oleh faktor-faktor lain.Hal ini menunjukkan bahwa budaya organisasi berpengaruh terhadap kinerja. Dari pengujian hipotesis diperoleh $\mathrm{t}$ hitung $>\mathrm{t}$ tabel atau $(6.399>1.674)$, sehingga $\mathrm{H}_{0}$ ditolak dan $\mathrm{H}_{1}$ diterima artinya terdapat pengaruh yang positif dan signifikan secara parsial antara budaya organisasi terhadap kinerja karyawan

3. Berdasarkan hasil penelitian, menunjukkan bahwa kepemimpinan dan budaya organisasi berpengaruh positif terhadap kinerja karyawan Bank DKI Cabang Pembantu Pondok Labu Jakarta Selatan dengan persamaan regresi $\mathrm{Y}=15.293+0.364 \mathrm{X}_{1}+0.632$ $\mathrm{X}_{2}$.Hasil analisis regresi menunjukkan koefisien kepemimpinan sebesar 0.364 bertanda positif dan budaya organisasi sebesar 0.632. Semakin baik kepemimpinan yang dijalankan maka akan semakin baik pula kinerja 
karyawan. Demikian pula sebaliknya, kepemimpinan yang dijalankan kurang baik maka kinerja juga akan mengalami penurunan. Demikian pula dengan budaya organisasi. Kontribusi pengaruh kepemimpinan dan budaya organisasi adalah sebesar $48.4 \%$ meskipun tergolong sedang namun positif. Dari pengujian hipotesis menggunakan uji statistik $F_{\text {hitung }}=$ $23.912>3,180$ atau $\left(F_{\text {hitung }}>F_{\text {tabel }}\right)$ sehingga $\mathrm{H}_{0}$ ditolak dan $\mathrm{H}_{1}$ diterima. Artinya terdapat pengaruh positif dan signifikan secara simultan antara kepemimpinan dan budaya organisasi terhadap kinerja karyawan.

\section{Saran}

Berdasarkan hasil penelitian yang telah dilaksanakan, maka saran yang dapat disampaikan sebagai berikut :

1. Pada variabel kepemimpinan, indikator yang paling lemah adalah pada pernyataan nomor 5 yaitu keberanian pimpinan dalam mengambil keputuan dimana hanya mendapat score3.7\%, meskipun termasuk dalam kategori baik, namun mengingat masih ada responden yang kurang setuju, tidak setuju dan sangat tidak setuju sebesar $(32.2 \%+0.9 \%+0.2 \%)=$ $33.3 \%$. Maka untuk lebih baik lagi organisasi harus lebih berani dalam mengambil keputusan terutama pemimpin.

2. Pada variabel budaya organisasi, indikator yang paling lemah adalah pada pernyataan nomor 2 yaitu memiliki kebebasan di organisasi dalam bertindak dan pengambilan keputusan, dimana hanya mendapat score $13.0 \%$, meskipun termasuk dalam kategori baik, namun mengingat masih ada responden yang kurang setuju, tidak setuju dan sangat tidak setuju sebesar $(29.8 \%+$ $0,5 \%+0 \%)=30.3 \%$. Maka untuk lebih baik lagi organisasi harus lebih memberi kebebasan di dalam organisasi dalam bertindak dan pengambilan keputusan.

3. Pada variabel kinerja karyawan, indikator yang paling lemah adalah pada pernyataan nomor 9 yaitu dalam melaksanakan pekerjaannya karyawan bekerjasama dalam memecahkan maslalah dimana hanya mendapatkan score $13.0 \%$, meskipun termasuk dalam kategori baik, namun mengingat masih ada responden yang kurang setuju, tidak setuju dan sangat tidak setuju sebesar $(26.0 \%+0.8 \%+0 \%)=$ $26.8 \%$. Maka untuk lebih baik lagi organisasi harus lebih mengutamakan untuk bekerjasama dengan team agar tercapainya tujuan organisasi.

4. Pengaruh secara simultan dari kepemimpinan dan budaya organisasi terhadap kinerja karyawan sebesar $48.4 \%$, nilai pengaruh ini masih bisa ditingkatkan lagi dengan cara selalu meningkatkan kualitas kerja untuk kemajuan organisasi pada Bank DKI Cabang Pembantu Pondok Labu Jakarta Selatan.

\section{DAFTAR PUSTAKA}

Algifari.2010. “Statistika, Deskriptif Plus utnuk Ekonomi dan
Bisnis"Yogyakarta: UPP STIM YKPN

Anoraga, Pandji. 2009. “ Bumn, Swasta dan Koperasi”. Jakarta : Gramedia Utama.

Arikunto, Suharsimi. 2010. "Prosedur Penelitian Suatu Pendekatan Praktek". Jakarta : PT Rineka Cipta.

Darsono P. 2010. “Budaya Organisasi”. Jakarta : Nusantara Consulting.

Davis, Keith dan Newstrom. 2012. 
"Perilaku Dalam Organisasi". Jakarta : Erlangga.

Dessler, G. 2009. "Manajemen Sumber

Daya Manusia ".Jakarta : PT Indeks.

Ghozali, Imam. 2011. "Aplikasi Analisis Multivariate dengan program SPSS".Semarang : Badan Penerbit Undip.

Gomes, Faustino Cardoso. 2009. I

"Manajemen Sumber Daya Manusia". Yogyakarta :

AndiHandoko, H.T. 2008. "Manajemen Personalia dan Sumber Daya Manusia".Jakarta: PT Indeks

Hasibuan, Malayu S.P. 2012.

"Manajemen Sumber Daya

Manusia”. Jakarta : BumiAksara.

Kartono, Kartini. 2011. "Pemimpin dan Kepemimpinan".Jakarta : PT Raja GrafindoPersada.

Kreitner dan Kinicki. 2001.

"Organizational Behavior ". Boston : McGraw Hill.

Kusrianto, Bambang. 2010. "Manajemen Sumber Daya Manusia ".Bandung Sulita

Luthans, Fred. 2006. "Organization Behavior”.New York : Mc GrawHill.

Mangkunegara, AA Anwar P.2012.

"Evaluasi Kinerja SDM". Bandung : PT RefikaAditama.

Martoyo, Susilo. 2007. "Manajemen Sumber Daya Manusia”.Yogyakarta : BPFE.

Moeheriono. 2009. "Pengukuran Kinerja Berbasis Kompetensi”. Bogor GhaliaIndonesia.
Soekidjo.2009.Pengembangan Sumber Daya Manusia. Jakarta : PTRineka Cipta. Rahadi, Dedi Rianto.2010. "Manajemen Kinerja Sumber Daya Manusia”. Malang :Tunggal Mandiri Publishing.

Rivai Veithzal dan Mulyadi, Deddy. 2012. "Kepemimpinan dan Perilaku Organisasi".Jakarta : PT Raja Grafindo Persada

Robbins, Stephen P.2012. "Perilaku Organisasi”. Jakarta : PT Indeks

Robbins, Stephen dan Mary Coulter. 2012. “Manajemen”. Jakarta “ PT Indeks

Ruky, Achmad.2003. "Sumber Daya Manusia Berkualitas". Jakarta : GramediaPustaka Utama

Safroni, Ladzi.2012. “Manajemen dan Reformasi Pelayanan Publik dalam KonteksBirokrasi Indonesia".Surabaya : Aditya Media Publishing.

Salam, Darma Setyawan. 2007.

"Manajemen Pemerintahan
Indonesia". Jakarta :Djambatan.

Sanusi, Anwar.2012. "Metode Penelitian Bisnis".Jakarta : PT Salemba Empat.

Sarwono, Jonathan. 2012. "Metode Penelitian Kuantitatif dan Kualitatif". Yogyakarta : Graha Ilmu.

Schein, Edgar. 2010. "Organizational Culture and Leadership". Jossey : BassPublishers.

Singgih, Santoso.2009. "SPSS Statistik Parametik".Jakarta : PT Elex Media Komputindo. 
Siregar, Syofian.2010. "Statistika

Deskriptif Untuk Penelitian".

Jakarta : Rajawali.

Sugiyono.2014. "Metode Penelitian

Kuantitatif Kualitatif dan R \&

D".Bandung : CV Alfabeta.

Supangat, Andi.2008. "Statistika dalam

Kajian Deskriptif, Inferensi dan

NonParametric'.Jakarta :Kencana

Prenada media Group.

Sutrisno, Edy.2009. Manajemen Sumber

Daya Manusia.Jakarta : Kencana.

Suwatno dan Donni Juni Priansa . 2011.

"Manajemen Sumber Daya

Manusia.Dalam Organisasi dan

Bisnis ".Bandung : Alfabeta.

Terry, George R \& Rue, Leslie W. Rue.

2010. "Dasar-dasar Manajemen". Jakarta :Bumi Aksara.

Thoha, Miftah.2012. "Kepemimpinan

Dalam Manajemen”.Jakarta : PT

RajaGrafindo.

Umar, Husein. 2008. "Riset Pemasaran

Dan Perilaku Konsumen”. Jakarta

: PT Gramedia Pustaka.

Wibowo. 2010. "Budaya Organisasi”.

Jakarta : PT Raja Grafindo

Persada.

\section{Skripsi, Thesis}

Hendriawan.2014.'Pengaruh Gaya

\begin{tabular}{lrr} 
Kepemimpinan & Dan \\
Budaya & & Organisasi \\
Terhadap & & Kinerja \\
Karyawan & Pada & PT. \\
Dwimitra & \multicolumn{2}{c}{ Multiguna } \\
Sejahtera & Di & Kabupaten \\
Konawe & Utara & Provinsi \\
Sulawesi & \multicolumn{2}{c}{ Tenggara". }
\end{tabular}

Skripsi.Makassar

Universitas Hasanuddin.

Nurjanah.2008. "Pengaruh Gaya

Kepemimpinan Dan Budaya

Organisasi TerhadapKomitmen

Organisasi Dalam Meningkatkan

Kinerja Karyawan Studi Pada

Biro Lingkup Departemen

Pertanian".Tesis.Semarang :

UniversitasDiponegoro.

Pratama, Yoga.2012. "Pengaruh Budaya

Organisasi Terhadap Kinerja

Pegawai PadaKantor Kecamatan

Nanggung Kabupaten

Bogor".Skripsi.Depok :

Universirtas Indonesia.

Rahmah, Fifi.2016. "Pengaruh Budaya

Organisasi Terhadap Kinerja

Karyawan PadaPT Kalmar Jaya

Serpong".Skripsi.Jakarta :

Universitas Pamulang.

Rondonuwu, Andrie.2011. "Pengaruh

Kepemimpinan Transformasional

DanBudaya Organisasi Terhadap

Kepuasan Kerja Anggota

Kepolisian Di Polres Bogor

Kota".Tesis.Depok :

Universitas Indonesia.

Agus Sugianto, Frana.2011. "Pengaruh

Motivasi Kerja Dan

Kepemimpinan Terhadap Kinerja

Karyawan Studi Pada PT.

Madubaru Yogyakarta.

Yogyakarta : Universitas

Pembangunan Nasional Veteran.

Sumarni, Dede.2011. "Pengaruh

Kepemimpinan Dan Budaya

Organisasi Terhadap Kinerja. 